\title{
Pulmonary Paracoccidioidomycosis: Clinical, Immunological and Histopathological Aspects
}

\author{
Luz E. Cano ${ }^{1,2, *}$, Ángel Gonzálezi,2, Damaris Lopera1, \\ Tonny W. Naranjo ${ }^{1,3}$ and Ángela Restrepo ${ }^{1}$ \\ ${ }^{1}$ Corporación para Investigaciones Biológicas (CIB), \\ ${ }^{2}$ Escuela de Microbiología, Universidad de Antioquia (UdeA), \\ ${ }^{3}$ Escuela Ciencias de la Salud, Universidad Pontificia Bolivariana (UPB), \\ Medellin, \\ Colombia
}

This chapter is dedicated to the memory of a great scientist, a man of vision, a true mentor, Professor Henrique Leonel Lenzi, Emeritus Professor, Laboratory of Pathology, Instituto Oswaldo Cruz (Fiocruz), Rio de Janeiro,

Brazil

\section{Introduction}

The systemic endemic mycoses are a group of microbial pathologies affecting primarily the lower respiratory tract, often overlooked in the evaluation of community-acquired pneumonia. They form a heterogeneous group caused by dimorphic fungi that share similar characteristics. All of them have the respiratory tract as the portal of entry and from the lungs they may disseminate to the mucous membranes, the skin, and many other organs. Nonetheless, each fungal disease has specific characteristics concerning its clinical course, diagnosis, and management. Interestingly, specific geographical areas of the world have been associated with acquisition of these mycoses. The diagnosis may be difficult and delayed owing to the varied manifestations and the multitude of differential diagnoses (Bonifaz et al., 2011; Hsu et al., 2010).

The major endemic systemic mycoses include histoplasmosis, coccidioidomycosis, blastomycosis, paracoccidioidomycosis (PCM), and penicilliosis. All of them can cause disease in both immunocompetent and immunocompromised hosts, in particular, AIDS and organ transplantation patients, and more recently recipients of biological therapies, such as TNF inhibitors or antagonists. These mycoses have similar clinical and radiologic presentations but require different treatments. Furthermore, when they have spread to the lymph nodes or skin, they may mimic other pathologies such as leishmaniasis, lymphoma, and syphilis, among others (Bonifaz et al., 2011).

${ }^{*}$ Corresponding Author 
In addition, some of them have been reported outside of the endemic areas (Europe, Japan, USA), all cases occurring in immigrants, tourists, or workers returning from endemic countries (Buitrago et al., 2011; Poisson et al., 2007).

For these reasons, it is essential that physicians around the world be informed of the clinical characteristics of these fungal diseases in order to include them in their differential diagnosis of patients coming from or visiting the recognized endemic areas.

\section{Defining paracoccidioidomycosis (PCM)}

Paracoccidioidomycosis (PCM) is an endemic systemic mycosis caused by the thermally dimorphic fungus, Paracoccidioides brasiliensis. The infection is acquired after inhalation of the infectious particles (conidia) produced by the fungus's mycelia form present in its as yet unknown natural habitat (Restrepo \& Tobón, 2009; Restrepo et al., 2011). This fungal pathogen has two morphotypes, a mold at temperatures under $28^{\circ} \mathrm{C}$ that frequently reveals chlamydoconidia and more rarely conidia (size $<5 \mu \mathrm{m}$ ): the latter can transform into yeast cells under the influence of body temperature. In tissues and cultures at $35^{\circ} \mathrm{C}-37^{\circ} \mathrm{C}$, this fungus grows as a yeast resembling a pilot's wheel due to its multiple buds (Figure 1). Yeast cells are round to oval but quite variable in size $(4-40 \mu \mathrm{m})$.
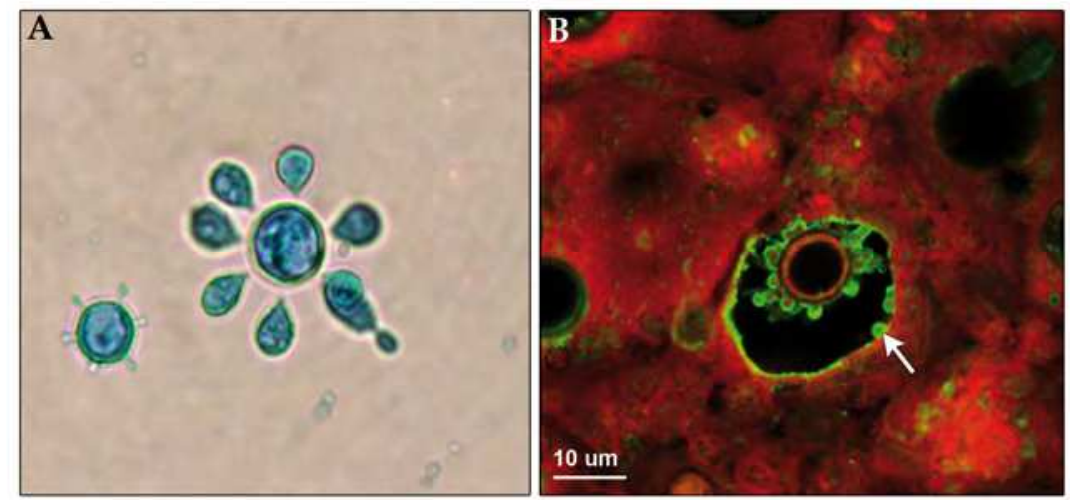

Fig. 1. P. brasiliensis budding yeast cells. (A) Pilot's wheel-like appearance of yeasts observed in a lactophenol cotton blue preparation from a colony grown at $36^{\circ} \mathrm{C}$. (B) Multiple budding yeast cells observed in lung tissue with small spheric buds (arrow), attached to or released (arrow) from a large mother cell. Confocal indirect immunofluuorescence for fibronectincovered P.brasiliensis yeast cells.

P.brasiliensis is only known in its asexual (anamorph) stage, but through molecular techniques it has been classified in the phylum Ascomycota, order Onygenales, family Onygenacea, close to Histoplasma capsulatum, Blastomyces dermatitidis, and Emmonsia parva phylogenetic tree, all of which have a teleomorphic, sexual stage in the genus Ajellomyces (Bialek et al., 2000b; Brummer et al., 1993).

More recently, the presence and expression of the mating type locus in several isolates of this fungus have been reported (Torres et al., 2010). Other studies have revealed that there are at least three distinct phylogenetic species, or clades, which are recognized within the genus (PS2, PS3, and S1) (Matute et al., 2006). In addition and based on high polygenetic 
diversity and exclusive morphogenetic characteristics, a different species, designated as P.lutzi, has been proposed (Teixeira et al., 2009).

\subsection{General concepts on ecology}

Geography sets PCM apart from other endemic mycoses of the Americas, such as histoplasmosis and coccidioidomycosis, as it is strictly confined to Latin America from Mexico at $23^{\circ}$ North to Argentina at $34^{\circ}$ South (Colombo et al., 2011; Nucci et al., 2009; Restrepo et al., 2011). The endemic areas are thus contained within the Tropics of Cancer and Capricorn (Bonifaz, 2010). PCM, however, is much more frequently reported in Souththan in Central-American countries respecting Chile, Surinam, the Guyana, Nicaragua and Belize and with rare exceptions (one case each in Trinidad, Grenada and Guadeloupe), also the Caribbean Islands (Lacaz et al., 2002; Restrepo et al., 2011). Brazil accounts for over $80 \%$ of all reported cases with Venezuela, Colombia, Ecuador, Bolivia and Argentina informing lesser proportion of cases (Colombo et al., 2011; Restrepo et al., 2011).

Additionally, this mycosis is not distributed homogeneously within a particular endemic territory but is concentrated in tropical and subtropical regions with abundant forests and waterways, high annual rainfall indices (1400-2999 mm), and mild temperatures $\left(17^{\circ} \mathrm{C}-\right.$ $24^{\circ} \mathrm{C}$ ) predominating throughout the year (Borelli, 1972; Calle et al., 2001; Restrepo et al., 2001). Soil texture and moisture availability are also important (Conti-Díaz, 2007; Restrepo et al., 2001), as found in Brazil by spatial and ecologic correlate analyses (Simões et al., 2004). Studies on this aspect discovered a cluster of juvenile patients with the acute or subacute form who were potentially connected to the 1982-83 El Niño Southern Oscillation (ENSO) climatic anomalies (Barrozo et al., 2010).

$P$. brasiliensis's microniche has not been pinpointed precisely because the few isolations from natural sources have been sporadic, with soil being the substrate most frequently mentioned (Franco et al., 2000). Presently, there are indications that the habitat is to be found near waterways or in humid areas also propitious to agricultural crops such as coffee, tobacco and sugar cane (Calle et al., 2001; Restrepo et al., 2001). One hypothesis postulated that fish and aquatic birds would be required around the microniche to allow survival and dispersion of the fungus in nature (Conti-Díaz, 2007). Of ecological importance is the regular isolation of the fungus from armadillos (Dassypus novemcinctus, Cabassous centralis) captured in the endemic areas, some of which revealed internal lesions (Bagaggli et al., 2003). Dogs and other domesticated and feral animals have also been implicated (Ricci et al., 2004; Richini-Pereira et al., 2008). Nonetheless, P. brasiliensis's microniche remains unknown despite many attempts to isolate it from suspected sites such as the permanent areas of residence of patients, in and around armadillos' burrows and their foraging areas (Restrepo et al., 2001).

Another circumstance that has hindered tracing the habitat has been the lack of information on outbreaks, which could have facilitated detection of the common source of infection (Lacaz et al., 2002; Restrepo et al., 2001). An increased number of childhood cases in areas where this disorder had previously been considered rare was noted by Coimbra et al. (1994) and Gonçalves et al. (1998), who suggested that colonization, gradual felling of the original native forests or changes in agricultural practices had probably exposed children to aerosolized fungal propagules, leading to increased disease rates. By the same token, in their study of 1,000 patients, Bellissimo-Rodrigues et al. (2011) pinpointed an area with the highest number of juvenile PCM cases, all of whom had resided close to coffee plantations, thereby raising the possibility of aerosol infection through agriculture-related work. None of 
the above reports, however, mentioned attempts at isolating the fungus from the environment.

Another important blocking factor in the search for the fungus's habitat is its capacity to enter prolonged quiescent stages, which has been demonstrated by the approximately 90 imported cases reported from nonendemic countries, as exemplified by the patients recently diagnosed in Europe (Buitrago et al., 2011; Mayayo et al., 2007; Poisson et al., 2007). All patients corresponded to emigrants living in Japan, the USA, Canada or several of the European countries where they had lived for a mean of 14 years after abandoning their native PCM-endemic homelands (Lacaz et al., 2002; Nucci et al., 2009; Shankar et al., 2011). These data clearly reveal $P$. brasiliensis's ability to enter prolonged latency, to revive without notice and cause clinically manifested disease. This latency period prompted Borelli to create the term reservarea to indicate the site where the primary infection is thought to have occurred and distinguishing it from the site, the endemic area, where the infection was diagnosed (Borelli 1972).

\subsection{General concepts on epidemiology}

\subsubsection{Distribution by age}

The disease is relatively uncommon in children and adolescents with approximately $2 \%$ of all patients less than 10 years of age and $8 \%$ less than 20 years old. (Bellissimo-Rodrigues et al., 2011; Paniago et al., 2003; Shankar et al., 2011). Clinically manifested PCM occurs, consequently, more often $(>80 \%)$ in adult patients 30-60 years old with the fourth decade of life presenting the largest number of cases (Colombo et al., 2011; Nucci et al., 2009; Paniago et al., 2003). The predominance of adult patients is reflected in higher mortality rates for those within this age group (Bittencourt et al., 2005; Coutinho et al., 2002; Prado et al., 2009; Santo, 2008). Although co-existence of the mycosis with HIV infection is relatively uncommon, $4 \%-5 \%$ according to data in the two largest series of cases published in Brazil (Belissimo-Rodrigues et al., 2011; Morejon et al., 2009), this dual infection has introduced a significant change in age distribution as these patients are younger (mean, 34 years of age) than the PCM non-AIDS cases (mean, 45 years of age).

\subsubsection{Distribution by gender}

Gender differences are also important markers of this fungal disorder, with adult males exhibiting overt disease much more often than females (Bellisimo-Rodrigues et al., 2011; Lacaz et al., 2002; Restrepo et al., 2011). Data taken from different series encompassing 5,500 patients revealed that 5,045 were males and 455 females for a male-to-female ratio of 11.1 to 1 (Shankar et al., 2011). In the largest Brazilian series totaling 1,000 patients, the male-tofemale ratio was lower: 6 to 1. It should be noted that important variations have become apparent when comparing the series with the lowest ratio of 5.3 to 1 reported in Brazil by Blotta et al. (1999) and the highest 70.6 to 1 reported by Shankar et al. (2011) for Colombia. These findings indicate that present knowledge is insufficient to explain the male-to-female differences according to country of residence and indicate that inter-country variability needs further study.

The difference in the incidence of overt PCM between adult men and women has also been explained on hormonal grounds. In 27 women with the mycosis, $70 \%$ had menopausal signs and in $11 \%$ hysterectomy had been performed (Severo et al., 1998). Interestingly, in a series of 95 children with PCM collected from various Brazilian reports, there were 51 boys and 44 
girls for a 1.16 to 1 ratio (Shankar et al., 2011). Such results contrast sharply with the 11.1 to 1 ratio recorded for overt PCM in adults. Since in children hormonal expression has not yet been fully developed, the finding of an almost equal gender distribution in prepubertal patients strengthens the protective role of hormones in this fungal disorder.

Additionally, in the experimental mouse model of PCM infection, differences in male and female animals have been noted. The fungus secretes a 17 beta estradiol-binding protein that attaches to the female hormone, regulating protein expression and hindering the mycelia to yeast transition so that in females fungal development is halted and the infection is controlled. On the other hand, in males conidia transform promptly into yeast cells and these multiply actively, resulting in progressive infection (Shankar et al., 2011). Additionally and as will be explained below, females exhibit a more active cellular immune response capable of halting the progress of the infection.

\subsubsection{Distribution by occupation}

Approximately $60 \%$ of the patients with active PCM work or have worked in agriculturerelated jobs, notably in tobacco, coffee and sugarcane fields (Calle et al., 2001; Colombo et al., 2011; Nucci et al., 2009; Paniago et al., 2003). Other occupations mentioned in large series are masonry, bricklaying and mining, as well as lumberjacking in indigenous forests. These occupations are, ultimately, associated with inhalation of dust (Conti-Diaz \& Calegari, 1979; Lacaz et al., 2002; Paniago et al., 2003; Restrepo et al., 2011). Even though residence in rural areas is a common trait among PCM patients, migration to urban settlements would be accompanied by a change in jobs so that when the diagnosis is established in these secondary localities, the medical history may record a different, non-PCM-related occupation. Additionally, recent land exploitation methods rely on insecticide application and soil burning, as done in sugarcane plantations, which should kill the fungus if present in the soil (Nucci et al., 2009; Restrepo et al., 2011). As a consequence, human exposure would no longer be as common; however, further observations are required to fully understand this point.

\subsubsection{Incidence and prevalence}

Despite the measures being implemented in Brazil, PCM is not yet a reportable disease, with the exception of the States of Mato Grosso do Sul, Minas Gerais and São Paulo (BellissimoRodrigues et al., 2011). Consequently, prevalence and incidence rates are not fully dependable. Coutinho et al. (2002) reported an annual incidence rate of 1-3 per 100,000 inhabitants, and, based on 3,181 deaths known to have occurred as a result of PCM, a mean annual mortality rate of 1.45 per million inhabitants was estimated with a nonhomogenous spatial distribution among Brazil's regions and states. The authors concluded that PCM was important because it was the eighth cause of death from predominantly chronic or recurrent types of infections and parasitic diseases. It also had the highest mortality rate among the systemic mycoses but had low visibility. The great majority of deaths occurred in males $(84.75 \%)$ and in the older age groups.

Bittencourt et al. (2005) analyzed 551 deaths of the mycosis in Parana State, Brazil, with an average annual mortality rate of 3.48 per million inhabitants, accounting not only for the fifth cause of death among the predominantly chronic infectious diseases, but also the highest mortality rate among the systemic mycoses. Santo (2008) reviewed 1,950 PCM death certificates finding that the largest number of deaths had occurred in men in the older age 
groups and among rural workers. The largest series of cases ever published (BellissimoRodrigues et al., 2011) analyzed 1,000 Brazilian PCM patients and indicated that in the 19801999 period, the incidence rates for the Riberão Preto district in São Paulo State were equivalent to a mean of 2.70 cases per 100,000 inhabitants. Colombian estimates show a much lower incidence rate, with the highest being 0.24 per 100,000 inhabitants. Since these were annual mean mortality rates calculated on the basis of 7,482 deaths reported to be caused by PCM, the figures varied from 1.45 to 3.48 per one million inhabitants (BellissimoRodrigues et al., 2011).

The importance of this mycosis can be inferred by the high burden of deaths occurring among the working population in individuals aged 30-60 years, mostly men engaged in agriculture (Bellissimo-Rodrigues et al., 2011).

\subsection{Clinical presentations}

PCM presents a gamut of clinical manifestations grouped according to the organs involved and the duration of the disease (Franco et al., 1987; Restrepo et al., 2008). Depending on the age and immune status of the host and on the size of the inhaled fungal inoculum, infection could be asymptomatic or may give rise to several different forms of disease. In immunocompetent individuals, they usually overcome fungal invasion; nonetheless, the fungus could remain quiescent, and a latent infection may be established. Four different clinical presentations are recognized, as follows.

\subsubsection{Subclinical infection}

After inhalation of the fungal particles, individuals may develop minor pulmonary symptoms that cannot be differentiated from those produced by other agents of pneumonia. The clinical manifestations often resolve spontaneously without medical intervention; however, the fungus could persist in a latent form and may later give rise to disease through endogenous reactivation, an event that may coincide with an alteration of the host's immune response (Benard et al., 2005). In some cases, the initial infection may leave a residual lung lesion. The latter situation presents the so-called regressive form of PCM. The latency process is known to exist and is frequently prolonged (mean, 14 years), as revealed by the cases reported outside the endemic areas (Buitrago et al., 2011; Walker et al., 2008; Shankar et al., 2011).

\subsubsection{Acute/subacute or juvenile-type disease}

This form of the mycosis is the result of the progression of a unresolved initial infection. The acute/subacute progressive form is seen mainly in undernourished children and adults less than 30 years of age and is the form observed in immunosuppressed individuals, such as those with HIV infection. The juvenile form is characterized by predominant involvement of the reticuloendothelial system. The mean duration of symptoms at consultation is 60 days and the most frequently involved organs are lymph nodes, skin, liver and spleen; less frequently bone marrow, stomach, small bowel, bones and joints are also invaded (Benard et al., 1994; Londero et al., 1996; Mendes, 1994; Morejon et al., 2009; Pereira et al., 2004).

\subsubsection{Chronic or adult-type disease}

This is the most frequently reported form of PCM, it has a prolonged course (months to years) and is diagnosed mainly in patients ranging from 30 to 50 years of age. This clinical 
form is characterized by significant lung damage as well as extrapulmonary manifestations. The respiratory symptoms become apparent only after several years with productive cough seen in $50 \%$ of the patients. Physical examination reveals few abnormalities even if extensive radiographic alterations are noted. The scarcity of respiratory symptoms explains why patients seek medical consultation based mainly on extrapulmonary manifestations, such as the presence of mucosal and skin lesions (Gomes et al., 2008; Marchiori et al., 2011; Mendes, 1994; Tuder et al., 1985). Besides the lungs, the most frequently compromised organs are the oral mucosa (involving oropharynx and larynx), skin and adrenal glands. Less frequently, the nasal and anal mucosa, genital organs and central nervous system may also be attacked. Mucosal lesions may be single or multiple, are progressive and destructive, giving rise to bleeding and pain, and are accompanied by dysphonia, dysphagia and sialorrhea.

\subsubsection{Residual form}

This form manifests the sequelae of prior disease at a moment when fungal growth has been arrested and the patient has overexpressed his immune responses to the point of developing fibrosis. This is exemplified by the chronic form of the mycosis where the lungs support the most prominent fibrotic changes, a complication recorded in approximately $60 \%$ of the patients (Funari et al., 1999; Naranjo et al., 1990; Tobón et al., 1995, 2003; Tuder et al., 1985). The chronic progressive adult form often precedes the establishment of the residual form. In most cases, when the patient is finally diagnosed, this sequela is already present, reflecting the corresponding structural and functional alterations (Benard et al., 2005; Bethlem et al., 1999; Lacaz et al., 2002; Restrepo et al., 2008). It is noteworthy that residual lesions do not respond to antifungal treatment. Pulmonary fibrosis is an incapacitating disorder that may lead to core pulmonale and, finally, to death (Tobón et al., 2003; Tuder et al., 1985).

In the differential diagnosis of PCM, various diseases including tuberculosis, histoplasmosis, leishmaniasis, malignancies, lymphomatous disorders and certain abdominal syndromes should be considered (Campos et al., 2008; Nogueira et al., 2006; Ramos \& Saraiva, 2008). It is important to note that PCM may coexist with tuberculosis in approximately $10 \%$ of the cases (Gomes et al., 2008; Quagliato et al., 2007).

\subsection{Establishing the diagnosis}

Diagnosis of PCM is based on the identification and isolation of the fungus. The microscopic visualization in representative clinical samples (including respiratory specimens or biopsies) of multiple budding yeast cells with a pilot's wheel-like appearance by direct $\mathrm{KOH}$ preparations or special stains, establishes the diagnosis (Lacaz et al., 2002; Nucci et al., 2009; Restrepo et al., 2009, 2011). Isolation of the fungus in culture is considered the gold standard and is successful in $60-85 \%$ of the cases. Additionally, serologic and immune-based tests [including agar gel immunodiffusion, complement fixation, enzyme-linked immunosorbent assays (ELISA) and antigen detection] are also frequently employed. These laboratory tests have great value and can also be employed in follow-up studies (Gómez et al., 1997, 1998; Lacaz et al., 2002; Nucci et al., 2009; Restrepo et al., 2009, 2011). In addition, in the last decade, molecular tests to diagnose PCM have been implemented; these tests require further research (Buitrago et al., 2011; Gomes et al., 2000; Bialek et al., 2000a; Koishi et al., 2010).

\subsection{Therapeutic options}

Treatment of PCM should be implemented according to the disease form; in addition, adequate nutrition, control of associated diseases, and measures to stop smoking must be 
implemented. Treatment of this mycosis includes sulfonamides, amphotericin B and azoles (Quagliato et al., 2007). Thus, in the case of minor and moderate forms of PCM, the combination of trimethoprim-sulfamethoxazole can be used (Shikanai-Yasuda et al., 2008). In cases of severe illness, treatment must be implemented using amphotericin B and continued with an oral antifungal, preferably itraconazole (Quagliato et al., 2007). Among the azoles, the latter is the drug of choice as it is effective in $98 \%$ of cases, irrespective of the clinical form, and has a low relapse rate (3\%) (Naranjo et al., 1990; Shikanai-Yasuda et al., 2002). Nonetheless, it may not be possible to eradicate the etiologic agent completely, and the risk of endogenous reactivation may persist. Treatment of PCM is prolonged, usually taking 6 months to 1 or maximum 2 years, but in general it should continue until clinical manifestations are resolved, except for those due to residual fibrotic sequelae (Hahn et al., 2000; Shikanai-Yasuda et al., 2002).

\section{Pathogenesis of experimental PCM in mice}

Animal models are excellent tools to study the pathogenesis of the different infectious diseases. In order to understand the pathogenesis of PCM, different animal models of this mycosis have been established, using different hosts such as mice (Calich et al., 1985; Cano et al., 2000; Defaveri et al., 1982; McEwen et al., 1987; Moscardi \& Franco, 1980), hamsters (Essayag et al., 2002; Iabuki \& Montenegro, 1979; Peraçoli et al., 1982), guinea pigs (FavaNetto et al., 1961) and rats (Iovannitti et al., 1999). All of these are powerful tools to explore the molecular and cellular aspects of PCM pathogenesis. The ability to control multiple variables in the establishment of the experimental models allows simulation of the human disease states and monitoring their course quantitatively. Therefore, animal models are a useful alternative to study the kinetics of the mechanisms involved in the pathogenesis of PCM.

\subsection{Establishment of a pulmonary PCM model induced by $\mathbf{P b}$-conidia}

Problems determining the initial stages of the host- $P$. brasiliensis interaction in humans when the fungal habitat is unknown indicate that an animal model of pulmonary PCM that would mimic, as closely as possible, human disease is needed. Such a model was established by the intranasal administration of $\mathrm{Pb}$-conidia to male BALB/C mice to be studied sequentially during the course of infection (McEwen et al., 1987; Restrepo et al., 1992). In this model, we have determined certain immune, histological and radiological aspects of pulmonary lesions by histopathology (early and chronic periods) (González et al., 2008a, b, c; Lopera et al., 2010, 2011) as well as by high-resolution computed tomography-HRCT (chronic periods) (Lopera et al., 2010). The local immune response has been measured by determining different cytokines in supernatants of pulmonary homogenates (González et al., 2003, 2005b, 2008d; Naranjo et al., 2010).

\subsection{Early immunological and histopathological findings in the model}

It has been hypothesized that once $P$. brasiliensis conidia reach the lung, they interact initially with the extracellular matrix (ECM) proteins (expressed predominantly in lung tissue), lung epithelial cells (which also express these ECM proteins on their own surface), alveolar macrophages (M $\phi s)$ and pulmonary dendritic cells. In addition, it has been reported that the different fungal morphotypes of $P$. brasiliensis (conidia, yeast cells and mycelia) exhibit on their surface adhesin-type molecules that allow both binding to several ECM proteins - 
mainly fibronectin, fibrinogen and laminin - and adherence to epithelial cells (Caro et al., 2008; González et al., 2005a, 2008a, b; Hernández et al., 2010). Activation of pulmonary cells, mainly $\mathrm{M} \phi \mathrm{s}$, took place after fungal interaction, thus initiating the inflammatory process through production of pro-inflammatory cytokines and chemokines, which in turn induced the expression of adhesion molecules on the leukocytes' surface (González et al., 2003, 2005b).

\subsubsection{Early pulmonary inflammatory process}

During the first 4 days post-infection, an acute inflammatory process, composed mainly of polymorphonuclear neutrophils (PMNs) and M $\phi s$, was observed in the lungs (Cock et al., 2000; González et al., 2003, 2005b; Restrepo et al., 1992). At the histopathological level, this inflammatory event concurred with a bronchopneumonic process in which PMNs and M $\phi s$ accumulated and fused with each other to constitute extensive, ill-defined masses, located inside the alveolar and the surrounding peribronchiolar spaces, resulting in involvement of approximately $40 \%$ of the lung's area (Cock et al., 2000; González et al., 2005b; Restrepo et al., 1992). It should be noted that during the first 3 days post-challenge, eosinophils and lymphocytes were also observed at the perivascular level (González et al., 2005b). After the $4^{\text {th }}$ day post-challenge, the cellular infiltrate was replaced by mononuclear cells, mainly M $\phi s$. The results of additional studies conducted in bronchoalveolar lavage fluids (BALs) coincided with the in situ description, with predominance of PMNs and M $\phi s$ during the period indicated (González et al., 2003). Interestingly, at the end of the $2^{\text {nd }}$ week postinfection, the inflammatory process decreased, indicating transient control of fungal invasion (González et al., 2005b).

Similarly, high levels of pro-inflammatory cytokines [interleukin (IL)-1 $\beta$, IL-6, tumor necrosis factor-alpha (TNF- $\alpha$ ) and chemokine, macrophage inflammatory protein (MIP)-2)] were recorded, especially in the pulmonary compartments and during the first 4 days postchallenge, (González et al., 2003). The production of these molecules by both inflammatory and endothelial cells accounted for the recruitment of certain inflammatory cells indirectly through induction of adhesion molecule expression, which in turn mediated migration of the inflammatory cells into the injured tissue (Tracey \& Cerami, 1994). In accordance with the above results, a significant decrease in the mouse pulmonary fungal burden occurred after the first 2 days post-challenge (Cock et al., 2000; González et al, 2005b).

\subsubsection{Expression of adhesion molecules and extracellular matrix proteins in the lungs}

Adhesion molecules expressed on the cell's surface of both leukocytes and endothelial cells are important mediators in the recruitment of leukocytes to sites of inflammation including the lungs (Albeda et al., 1994; Pilewski \& Albelda, 1993). Expression of these adhesion molecules is induced by the production of pro-inflammatory cytokines such as TNF- $\alpha$ and IL-1 (Osborn et al., 1989; Masinovsky et al., 1990), which have been reported as important inflammatory components in a variety of lung diseases including those caused by fungi (Hamacher \& Schaberg, 1994; Izzo et al., 1998; Yokomura et al., 2001; Yu \& Limper, 1997). In our PCM mouse model, we have observed that lungs of mice infected intranasally with P.brasiliensis conidia show a higher expression of adhesion molecules during the first 4 days post-challenge. Thus, the intercellular adhesion molecule-1 (ICAM-1) was overexpressed mainly on bronchiolar epithelium, vascular endothelium, pneumocytes and M $\phi$; the vascular cell adhesion molecule-1 (VCAM-1) was also overexpressed but only in the 
vascular endothelial cells, while CD18 and Mac-1, two molecules belonging to the $\beta_{2}$ integrin family, were strongly expressed on PMNs and M $\phi s$ (González et al., 2005b).

In lungs of mice infected with $P$. brasiliensis conidia, an initial deposition of fibrin-like material was detected after 2 days post-infection. In addition, an increased deposition and rearrangement of the following ECM proteins - laminin, fibronectin, fibrinogen, collagen and proteoglycans - were observed not only at the beginning of infection, but also during the late periods of fungal infection (González et al., 2008c). Interestingly, this increased deposition of ECM proteins in the lungs of infected mice was accompanied by a marked afflux of pro-inflammatory cells (González et al., 2008c).

In addition, $P$. brasiliensis is known to express adhesin-like molecules on its surface that recognize and bind to ECM proteins (Barbosa et al., 2006; González et al., 2005a). More recently, in elegant experiments using antisense technology, the role of a $P$. brasiliensisadhesin molecule was confirmed when a 32-kDa protein, a putative adhesion member of the haloacid dehalogenase (HAD) superfamily of hydrolases, conferred both adherence capacity to pulmonary human epithelial cells and virulence in a mouse model of infection (Hernández et al., 2010)

The observations described above may suggest that ECM proteins modulate the pathogenesis of PCM by means of two mechanisms: 1) participation in the migration of proinflammatory cells into the lungs and 2) serving as a binding protein for P. brasiliensis expressing on its surface adhesin-like molecules (receptors). These interactions may serve the fungus both for attachment to host tissue (evading the physical barriers) and dissemination to other organs, contributing in this manner to the establishment of the disease process.

\subsubsection{Expression by pulmonary phagocytes of microbicidal molecules}

During any infectious process, phagocytic cells are the main effector cells, which upon their activation (e.g., by cytokines), produce microbicidal substances [i.e., degradative enzymes, defensins, lysozymes, reactive oxygen intermediates (ROS) and reactive nitrogen intermediates (RNI)] capable of inhibiting and destroying several pathogens (Nathan \& Shiloh, 2000; Newman et al., 2000).

Taking into account that both PMN and M $\phi$ s are the principal components of the pulmonary inflammatory infiltrate of mice infected with $P$. brasiliensis conidia, the expression of microbicidal molecules produced by these phagocytic cells in the PCM model was determined. In vivo studies failed to detect nitric oxide (NO) production or inducible nitric oxide synthase (iNOS, the enzyme responsible for NO production) during the early days post-challenge in the lungs of mice infected with $P$. brasiliensis. Interestingly, as will be described below, a higher expression of iNOS was observed in the late periods of infection (González et al., 2008d). In additional studies, we observed an increase of in situ lysozyme expression (PMN and M $\phi$ s) in the lungs of mice infected with P. brasiliensis conidia during the first 4 days post-challenge. This expression was accompanied by a decrease in the number of fungal propagules (González et al., 2008), observations suggesting that lysozymes may exert an antifungal effect against $P$. brasiliensis.

Altogether, the above observations led us to propose a description of the initial mechanism triggered by the infection with $P$. brasiliensis conidia:

1. Once the conidia reach the lungs, they adhere to both ECM proteins and epithelial cells through the interaction with adhesins present on their own surface; in addition, the 
fungal cells may interact with alveolar M $\phi$ s or dendritic cells present on the alveolar space.

2. Once the adhesion process or the cellular interaction takes place, induction of the production of pro-inflammatory cytokines takes place, which in turn stimulates the expression of adhesion molecules with such expression modulating the migration of circulating inflammatory cells into the lung tissue. This event triggers a strong inflammatory process, enhancing cytokine and chemokine production as well as increasing the deposition and rearrangement of ECM proteins.

3. P. brasiliensis conidia will experience a transitional process to yeast cells if no inhibitory mechanism intervenes in such process.

4. Once the phagocytes are activated, they will express, or produce, microbicidal molecules capable of destroying the fungus.

5. If the fungus is able to overcome the fungicidal mechanisms exerted by the host's defenses, dissemination to other organs will occur, perhaps using their adhesins to bind to ECM proteins or by producing degradative enzymes able to cleave such ECM proteins. Finally, the disease process will become established.

\subsection{Chronic immune responses in the model}

The intranasal inoculation of $P$. brasiliensis conidia into BALB/c male mice resulted in a progressive disease characterized by an increase of CFUs in the lungs, with maximal values at the $12^{\text {th }}$ and $16^{\text {th }}$ week's post-infection (Franco et al., 1998). In addition, extrapulmonary dissemination to the spleen (week 4) and liver (week 12) will take place, as indicated by the isolation in culture of the fungus from these organs (McEwen et al., 1987).

Then, during the infectious process corresponding to the chronic stages, different immunological mechanisms such as inflammatory responses, cytokine production, metalloproteinase expression, nitric oxide participation, granuloma formation and, finally, the chronic pulmonary sequelae characterized by fibrosis enter into play, as described below.

\subsubsection{Production of cytokines}

Additionally, several studies on the cytokines implicated in the chronic stages of experimental PCM have demonstrated, through ELISA assays and the Multiplex system, that from the $4^{\text {th }}$ to the $8^{\text {th }}$ week post-challenge, infected mice exhibited a significant increase in IL-1 $\beta$, TNF- $\alpha$, IL-12p40, RANTES, MIG, PDGF-b, IL-13 and TGF- $\beta$. Even though these cytokines have been implicated in the formation and maintenance of granuloma, some of them (IL-1 $\beta$, TNF- $\alpha$, IL-13 and TGF- $\beta$ ) are also directly involved in fibrosis generation (Franco et al., 1998; Lopera et al., 2011; Naranjo et al., 2011; Wynn, 2007).

Other authors, using both male and female mice in a PCM experimental model, have shown different immune responses that are gender-dependent with high production of Th1 cytokines and T-beta expression by the paracoccin-stimulated cultures of spleen cells from infected female mice; in contrast, cells from infected males produced higher levels of the Th2 cytokines and expressed GATA-3 (Pinzan et al., 2010). These results were confirmed using mice that had been submitted to gonadectomy followed by inverse hormonal reconstitution, where spleen cells derived from castrated males reconstituted with estradiol had produced higher levels of IFN- $\gamma$ and lower levels of IL-10 than normal males in response to paracoccin stimulus. In contrast, spleen cells from castrated female mice that had been treated with testosterone 
produced more IL-10 and less IFN- $\gamma$ than cells from normal females (Pinzan et al., 2010). In conclusion, these results reveal that the sexual hormones had a profound effect on the biology of immune cells, with estradiol favoring protective responses against $P$.brasiliensis infection.

\subsection{2 iNOS expression and nitric oxide (NO) production in the lungs}

In this PCM pulmonary model, the role of the NO system was determined during the chronic immune response by means of lung biopsies from infected mice. We developed an immunohistochemical stain for iNOS (NOS2) and observed that this enzyme was expressed mainly in vivo by the epithelioid histiocytes, with its maximal expression occurring 12 weeks after infection (González et al., 2008d). The expression of iNOS correlated significantly $(\mathrm{r}=0.77891)$ with the number of granulomas present in the pulmonary parenchyma (González et al., 2008d), suggesting that at this stage iNOS induction may depend on factors or mechanisms related to the environment in the granuloma (Goldman et al., 1996).

In addition, the in vivo administration of aminoguanidine (a highly specific inhibitor of iNOS) to $P$. brasiliensis-infected and noninfected mice induced in the former a significant reduction of their survival in comparison with negative control mice. These results suggest that during the chronic stages (12-17 weeks post-infection), the NO system played an important protective role against fungal infection (González et al., 2008d). This effect has also been observed in a model of latent tuberculosis (Flynn et al., 1998). However, Nascimento et al. (2002) proposed a dual role for nitric oxide in another experimental PCM model, where NOS2-derived NO would be essential for resistance to the fungus, but its overproduction would be associated with susceptibility.

Using NOS2-deficient mice, Livonesi et al. (2009) demonstrated that this enzyme is to be considered as a resistance factor during experimental PCM because it controls fungal proliferation, cytokine production, development of a high inflammatory response and consequently formation of necrosis. Other authors demonstrated that NO has an important role in granuloma modulation, by controlling osteopontin and MMP production, as well as by inducing loose granuloma formation and fungal dissemination, resulting, at later phases, in progression of experimental PCM (Nishikaku et al., 2009). However, iNOS-derived NO seems not to be the sole factor responsible for the immunosuppression observed during the infections caused by P. brasiliensis.

\subsubsection{Granulomatous inflammation in the lungs during experimental PCM}

The granuloma is the histologic hallmark of a variety of infectious and noninfectious processes, including PCM, all of which elicit chronic granulomatous inflammation. The word "granuloma" is derived from the Latin word granulum, which means a small particle of grain and, traditionally, is microscopically described as a compact, rounded aggregate of M $\phi s$ usually surrounded by a rim of lymphocytes that results in a response to chronic antigenic stimulation. Aggregation of $\mathrm{M} \phi \mathrm{s}$ is the minimum requirement of a granuloma, regardless of whether the lesion also contains necrosis, lymphocytes, plasma cells, or multinucleated giant cells (Mukhopadhyay \& Gal, 2010). The granuloma functions both as a niche in which some microorganisms can grow or persist and as an immunologic microenvironment in which cells interact to control and prevent dissemination of the eliciting pathogen (Flynn et al., 2011).

Pulmonary granulomatous inflammation in experimental PCM is a dynamic process that goes from dispersal parenchymal inflammation, to well-defined nodules, from periarterial 
sheath inflammation to pseudotumoral masses (Figure 2) (Lopera et al., 2011). The lung's area occupied by the inflammatory reaction increases gradually from 8 to 12 weeks after P.brasiliensis infection, involving up to $40 \%$ of the lung's area. In the following subsections, we will describe the structure and cellular composition of granuloma during the experimental infection; review the formation and maintenance of the granuloma reported in the literature and compare the main features of human and experimental pulmonary histopathology during the course of $P$. brasiliensis infection.
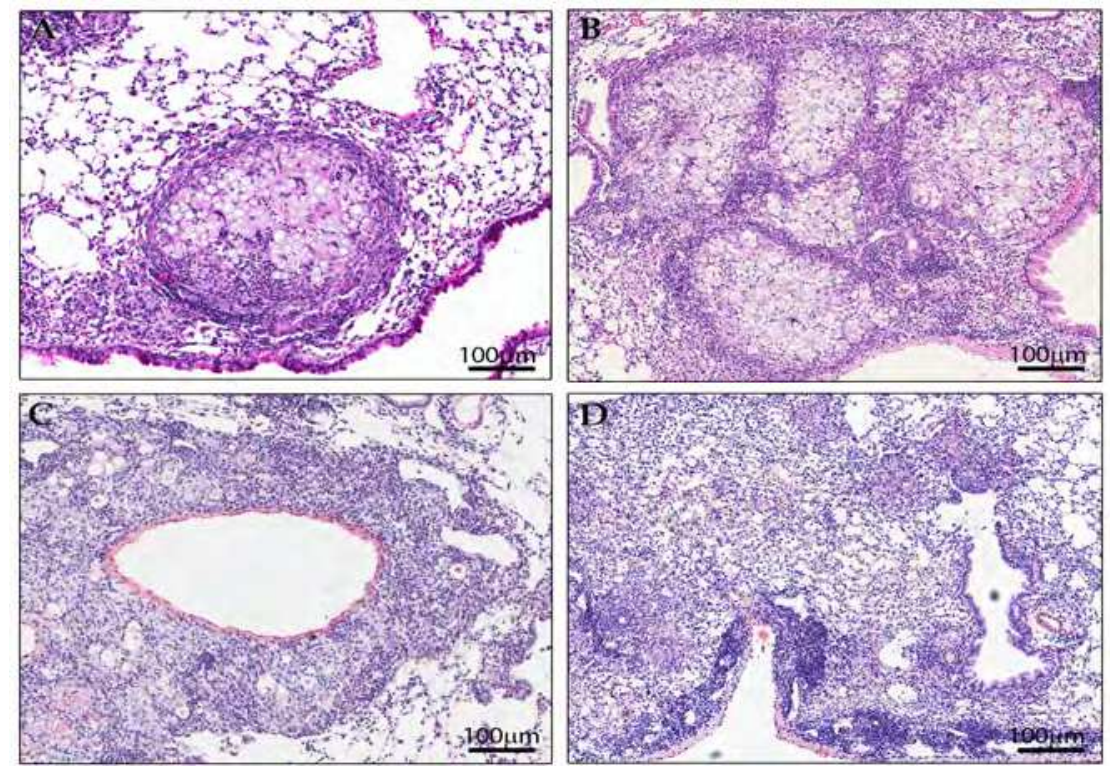

Fig. 2. Pulmonary lesions observed in BALB/c mice infected with P. brasiliensis conidia. (A) Well-defined nodules. (B) Confluent granulomas. (C) Periarterial sheath inflammation. (D) Dispersed parenchymal inflammation. H\&E stained slides, 10X.

Structure and cellularity of pulmonary lesions: The well-defined granuloma or the nodular pattern corresponds to multiple sphere-like or oval parenchymal granulomas adjacent to terminal bronchioles, about $400 \mu \mathrm{m}$ in diameter, sometimes isolated but becoming confluent as infection progresses. This is the predominant pattern throughout the infectious process in the lungs of BALB/c mice infected with $P$. brasiliensis conidia. In humans and experimental $\mathrm{PCM}$, the general structure of granuloma consists in two distinct zones: one noncollagenic central zone composed of $P$. brasiliensis yeasts and $\mathrm{M} \phi \mathrm{s}$, and one peripheral zone composed by lymphocytes and fibroblastoid-like cells (Kerr et al., 1988). However, the cellularity and pattern of lesions change as infection progresses. A summary of the main structural and cellular changes in the granulomas sequentially observed in the experimental model of PCM is presented below (Lopera et al., 2011).

During the early stages of granuloma development, 4 weeks post-infection in our experimental model, granulomas were composed of a central core or zone of M $\phi$ s and fungi with a frequent and intense infiltration by PMNs, sometimes presenting an apoptotic aspect. Some M $\phi$ s formed multinucleated giant cells. The central zones of the granulomas were 
surrounded by a fibroblast-like layer expressing concentric layers of reticular fibers with a lesser amount of interstitial collagen. The peripheral zone consisted of a noncontinuous halo of small lymphocytes, at times forming pseudofollicular lymphocyte aggregates. At this time, an intense and diffuse parenchymal inflammation, disposed near or around the granulomas, accompanied the pulmonary response to $P$. brasiliensis.

During the most chronic stages of the infection (8, 12 and 16 weeks), M $\phi$ s acquired a xanthomatous aspect, cholesterol crystals appeared in the central zone of the granuloma and a large number of mature plasma cells located at the periphery and mixed with the fibroblastic-like cells were observed. Besides well-defined granulomas, the peak of inflammation (8-12 weeks p.i.) was characterized by periarterial inflammation accompanied by lymphatic dilatation and edema. The cellular infiltrate defined the periarterial inflammatory sheaths with dispersed fungi (Figure 3) and more mature plasmocytes and eosinophils in comparison with the granuloma.
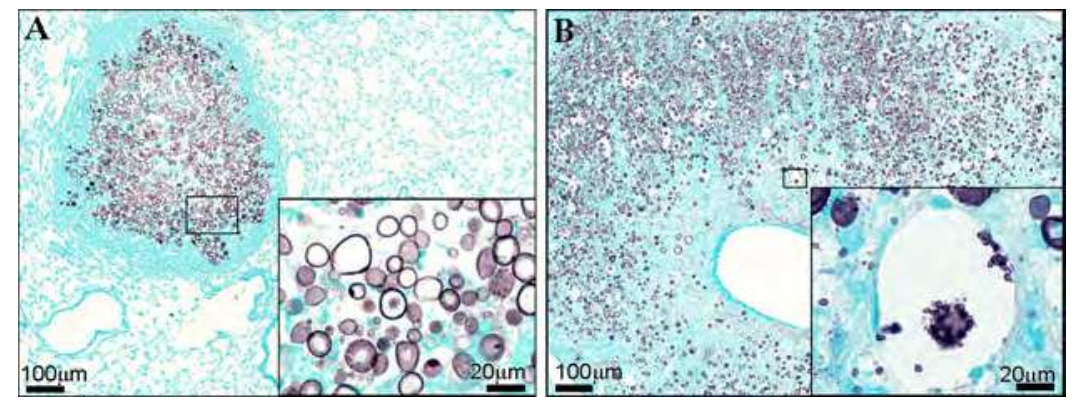

Fig. 3. Fungal aspects as seen in the lesions of a mouse with experimental pulmonary PCM. (A) Nodule full of fungi in the central area (10X), that present multiple-budding yeast cells with varying sizes (insert 100X). (B) Numerous fungi spread all over the periarterial space (10X), several of them presenting a special perifungal space (insert 100X). Grocott's stained slides.

Multiple granulomas fused and formed pseudotumoral masses or "paracoccidioidomas" five to six times larger than nodules $(2,000 \pm 194 \mu \mathrm{m}$ in length) were observed in the final period of evaluation (16 weeks p.i.) in this experimental model.

Formation and maintenance of $P$. brasiliensis-induced granuloma: The mechanisms that drive the migration of cells that will form and maintain the granuloma around P. brasiliensis have begun to be explored. However, important differences in the experimental models as concerns the infective propagules (conidia, yeast cells) and the fungal isolates used, as well as the route of inoculation and the experimental host's genetic background, makes conclusions difficult. Table 1 presents the main results of research that has analyzed the cells and mediators involved in $P$. brasiliensis-induced granulomatous inflammatory response centered on pulmonary findings.

The major biological significance of granuloma is the limitation of the infection to a local area. However, diffuse and loose granulomatous inflammation does not limit infection and is associated with incapacity to control the disease, as shown by the large number of fungal cells and the diminished survival time of infected animals (Livonesi et al., 2008, 2009).

An inflammatory response is necessary for disease control but it is also responsible for the typical immunopathology caused by diseases such as PCM that include tissue necrosis and cavitations in the center of granulomas. 


\begin{tabular}{|c|c|c|}
\hline Experimental model & Main results & Reference \\
\hline $\begin{array}{l}\text { Male BALB/c mice infected i.n. } \\
\text { with } 26 \times 10^{6} \text { viable or heat- } \\
\text { killed P.brasiliensis yeasts; or } \\
\text { inoculated with } 6.5 \times 10^{6} \\
\text { nonviable fragmented yeast } \\
\text { cells }\end{array}$ & $\begin{array}{l}\text { Granuloma formation required viable yeast cells or } \\
\text { conidia. Heat-killed } \mathrm{Pb} \text { yeasts or yeast fragments did } \\
\text { not induce granuloma formation. }\end{array}$ & $\begin{array}{l}\text { (Bedoya et al., } \\
\text { 1986; Cock et } \\
\text { al., 2000) }\end{array}$ \\
\hline $\begin{array}{l}\text { Rats infected i.p. with } \\
\text { P.brasiliensis yeasts }\end{array}$ & $\begin{array}{l}\text { Although most lesions developed in peritoneal cavity, } \\
\text { granulomas also appeared in lung. } \\
\text { Pulmonary granulomas were less collagenic than } \\
\text { those observed in omentum, diaphragm and liver. }\end{array}$ & $\begin{array}{l}\text { (Kerr, et al., } \\
1988)\end{array}$ \\
\hline $\begin{array}{l}\text { Male C57Bl/ } 6 \text { mice and IFN- } \gamma \\
\text { and TNF receptor p55-deficient } \\
\text { mice infected i.v. with } 1 \times 10^{6} \\
\text { P.brasiliensis yeast cells }\end{array}$ & $\begin{array}{l}\text { IFN- } \gamma \text { and TNF receptor p55-deficient mice were not } \\
\text { able to build organized granulomas, presented greater } \\
\text { number of fungi and high rates of mortality. }\end{array}$ & $\begin{array}{l}\text { (Souto et al., } \\
2000)\end{array}$ \\
\hline $\begin{array}{l}\text { Male } \mathrm{C} 57 \mathrm{BL} / 6 \text { and ICAM-1KO } \\
\text { mice infected } i . t \text {. with } 1 \times 10^{6} \mathrm{~Pb} \\
18 \text { yeast cells }\end{array}$ & $\begin{array}{l}\text { ICAM-1 was required for the early formation of } \\
\text { granulomas. In the absence of ICAM-1, granuloma } \\
\text { development delayed } 60 \text { days vs. } 30 \text { days in control } \\
\text { mice. }\end{array}$ & $\begin{array}{l}\text { (Moreira et al., } \\
2006)\end{array}$ \\
\hline $\begin{array}{l}\text { In vitro granuloma model } \\
\text { induced by gp } 43 \text {-coated beads }\end{array}$ & $\begin{array}{l}\text { In vitro granuloma formation required B1-cells and } \\
\text { M } \phi \text { s interaction. M } \phi \text { s alone were not able to migrate } \\
\text { to the beads and form granulomas. Soluble gp } 43 \\
\text { antigen-enhanced granuloma-like structure } \\
\text { formation. }\end{array}$ & $\begin{array}{l}\text { (Vigna et al., } \\
2006)\end{array}$ \\
\hline $\begin{array}{l}\text { BALB/c and BALB/Xid mice } \\
\text { infected i.t. with } 1 \times 10^{6} \mathrm{~Pb} 18 \\
\text { yeast cells }\end{array}$ & $\begin{array}{l}\text { Mice deficient in B1-cells (BALB/Xid mice) exhibited } \\
\text { smaller pulmonary granulomas with less fungi and } \\
\text { longer survival. Therefore, B1-cells participated in the } \\
\text { exacerbation of granulomatous lesions and increased } \\
\text { host susceptibility to infection. }\end{array}$ & $\begin{array}{l}\text { (Popi et al., } \\
2008)\end{array}$ \\
\hline $\begin{array}{l}\text { C57BL/ } 6 \text { IL-12p } 40^{-/-} \text {and WT } \\
\text { mice infected i.v. with } 1 \times 10^{6} \\
\text { Pb18 yeast. }\end{array}$ & $\begin{array}{l}\text { In the absence of the IL-12p40 subunit, involved in } \\
\text { both IL- } 12 \text { and IL- } 23 \text { formation, mice developed high } \\
\text { number of pulmonary granulomas without defined } \\
\text { delimitations associated with high number of yeast } \\
\text { cells. }\end{array}$ & $\begin{array}{l}\text { (Livonesi et al., } \\
2008)\end{array}$ \\
\hline $\begin{array}{l}\text { C57BL/6 iNOS }{ }^{-/-} \text {and WT mice } \\
\text { infected i.v. with } 1 \times 10^{6} \mathrm{~Pb} 18 \\
\text { yeast }\end{array}$ & $\begin{array}{l}\text { iNOS }{ }^{-/-} \text {mice showed granulomas with high } \\
\text { inflammatory response, central necrotic areas, diffuse } \\
\text { distribution of cells, incipient reticulin fiber pattern } \\
\text { and high number of yeast cells. }\end{array}$ & $\begin{array}{l}\text { (Livonesi et al., } \\
2009 \text { ) }\end{array}$ \\
\hline $\begin{array}{l}\text { BALB/c male mice infected i.n. } \\
\text { with } 4 \times 10^{6} \text { P.brasiliensis conidia }\end{array}$ & $\begin{array}{l}\text { Extracellular matrix proteins overexpressed and } \\
\text { suffered rearrangement process during the course of } \\
\text { infection. These ECM proteins localized surrounding } \\
\text { the granuloma. }\end{array}$ & $\begin{array}{l}\text { (Gonzalez et } \\
\text { al., 2008c) }\end{array}$ \\
\hline
\end{tabular}

Abbreviations: i.n.: intranasally, i.p.: intraperitoneally, i.t.: intratracheally i.v.: intravenously, $P b: P$. brasiliensis, WT: wild-type

Table 1. Contribution of cell subsets and molecules in pulmonary granuloma formation following infection with $P$. brasiliensis.

\subsubsection{Fibrosis as sequelae of PCM disease}

Pulmonary fibrosis is detected in several disorders with known or unknown etiologies (Datta et al., 2011). In this sense, this progressive and prominent complication is also 
observed in approximately $60 \%$ of patients suffering from the chronic form of PCM (Restrepo et al., 2008). Given that the P. brasiliensis microniche remains uncharacterized and taking into consideration the prolonged latency observed in PCM, the characteristics of the primary infection have not been defined, and great difficulties have arisen when sequentially evaluating the development of fibrosis attributed to this infection in humans. However, results from the experimental pulmonary PCM model have given convincing evidence as to the progress of this disease (González et al., 2008b).

In contrast with idiopathic pulmonary fibrosis (IPF) for which current research indicates that inflammation is of lesser importance with fibrosis appearing primarily as a disorder of fibroblast proliferation and activation in response to an as yet unknown trigger (Meltzer \& Noble, 2008), the development of fibrosis in PCM is a progressive event, resulting from a persistent antigenic stimulus leading to chronic inflammation and establishment of fibrosis mainly located in the perihilar region, the main bronchi and their branches, and the large pulmonary vessels (Restrepo et al., 2011). The functional limitation caused by the development of fibrosis may advance toward cor pulmonale, progressive lung incapacity and finally death (Restrepo et al., 2008; Tobón et al., 2003; Tuder et al., 1985).

The fibrosis process begins with acute injury caused by the interaction of $P$. brasiliensis conidia with ECM proteins and lung epithelial cells; this interaction is followed by chronic granulomatous inflammation with fibroblast proliferation and activation, an increase in ECM proteins predominantly composed of fibronectin, fibrinogen, collagen type I and III, as observed in the surroundings of the granulomas.

These EM proteins contribute to the establishment of fibronodular lesions that continue to advance even after appropriate antifungal therapy with itraconazole, a medication that effectively controls the active stage of this mycosis but does not hinder lung fibrosis (González et al., 2008a, c; Naranjo et al., 2010; Tobón et al., 2003).

Even though patients with chronic PCM show well-established pulmonary lesions at diagnosis, all of them are not in the same stage of infection development, explaining why, although not sequentially, several studies have been able to describe certain histological patterns present during the development of fibrosis in humans. Tuder et al. (1985) described the lungs of 12 patients with chronic PCM in histopathological terms and concluded that chronic pulmonary PCM is a disease that affects both lungs equally and that fibrosis is mainly related to the progressive course of the granulomatous reaction to cicatrization and, to a lesser degree, is probably due to direct induction by the fungi. This study described extensive areas of dense fibrosis close to the hilar region and involved structures such as the bronchi and lymph nodes with fibrosis extending as fibrous septa of variable thickness throughout the lung parenchyma (Tuder et al., 1985).

With the development of HRCT, several studies have been published demonstrating the correlation between histopathological and radiological findings, thus providing a more precise characterization of the pattern and magnitude of the lung abnormalities, as well as better follow-up of patients with chronic pulmonary PCM. In regards to fibrotic findings on chest tomography, this process has been described as thickening of interlobular and alveolar septa, primarily those interconnecting the granulomas (Marchiori et al., 2011). This has been correlated histopathologically with prominent collagen deposition, especially near the hilar regions, comprising lymph nodes, bronchi and the main pulmonary artery branches; additionally, pulmonary architectural alterations were also observed (Funari et al., 1999; Marchiori et al., 2011; Souza et al., 2006). 
Notwithstanding, in some patients, fibrosis development has been recorded in the absence of a clearly established granulomatous reaction, thus allowing speculation that the fungus itself might induce an active and higher collagen deposition (Marchiori et al., 2011; Tuder et al., 1985).

In reference to PCM animal models, several have been developed with the purpose of understanding the complete course of the disease; despite differences on the inoculum used (infective forms and concentration), fungal isolates, route of inoculation and host genetic background, the results have made it possible to define certain common phases during the granulomatous inflammation process (Burger et al., 1996; Calich et al., 1985; Da Silva et al., 2009; Xidieh et al., 1999). However, only the murine model of chronic pulmonary PCM in male BALB/c mice induced by the intranasal inoculation of naturally infective conidia has provided a reproducible model to observe in detail not only the characteristics of the inflammatory response induced by $P$. brasiliensis conidia, but also the important components of the PCM residual form (Cock et al., 2000; González et al., 2008a; Restrepo et al., 1992).

In the murine model described above, it was determined that at 4 weeks post-infection, when the granuloma are well shaped, thin fibers of collagen and reticulin became evident, suggesting the beginning of a fibrotic process, which progressed simultaneously with the presence of leukocyte infiltrates surrounding the granuloma (Lopera et al., 2010). After the $8^{\text {th }}$ week post-infection, thick fibers of collagen and reticulin became evident as an indicator of established fibrosis; fibers of both proteins gradually increasing up to 12 weeks postinfection indicated the collagenesis process reaching its highest intensity, with particular involvement of the periarterial space and the surrounding area of the granuloma (Figure 4), whether or not it was confluent. Observations made in the $16^{\text {th }}$ week post-infection revealed a well-established pulmonary fibrosis process (González et al., 2008b, c; Lopera et al., 2010; Naranjo et al., 2010).
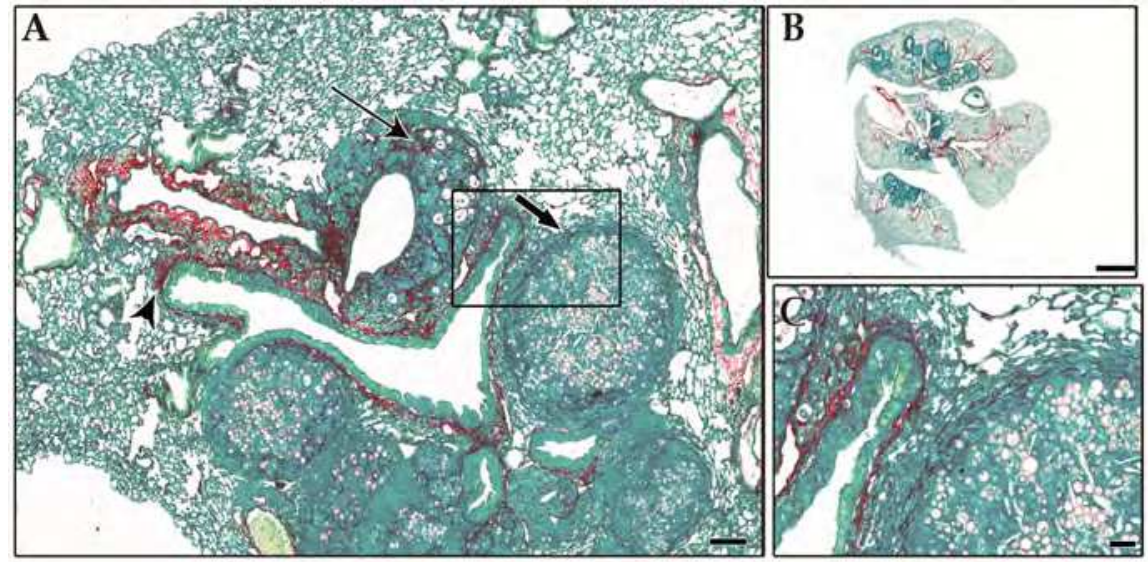

Fig. 4. Characteristics of lung fibrosis in P. brasiliensis infected mice. (A) Increased collagen (red fibers) noticed in the periarterial inflammatory reaction (thin arrow), in the periphery of granulomas (thick arrow) and in the bronchial wall (arrow's head). (B) Panoramic view of the entire lung. (C) Detail of collagen fibers deposition in the periphery of a granuloma and around a bronchus. Picrosirius and fast green (PIFG) stained lung sections. (Scale bars: $\mathrm{A}=$ $100 \mu \mathrm{m}, \mathrm{B}=2 \mathrm{~mm}$ and $\mathrm{C}=30 \mu \mathrm{m})$. 
One of the pathogenic mechanisms involved in the progressive accumulation of collagen and later development of fibrosis could be the disproportion between synthesis and degradation of ECM components such as reticulin and collagen, primarily due to an imbalance among the mediators of matrix degradation, metalloproteinases (MMPs) and their inhibitors (Garcia-de-Alba et al., 2010; Pardo \& Selman, 2006). The presence of MMPs, specifically collagenase MMP-1 and gelatinase-A MMP-2, and the tissue inhibitors of MMPs (TIMP-1) was evaluated using immune stain in the murine model of pulmonary PCM. The results indicated that 4 weeks after $P$. brasiliensis intranasal inoculation, $85 \%$ of infected mice expressed MMP-1 as MMP-2 and 71\% of them expressed TIMP-1, both with moderate intensity; at 16 weeks post-infection, almost all them showed equally positive immune stains to the TIMP-1 and MMPs evaluated, with the difference that close to $37 \%$ of them exhibited high stain intensity (Bárcenas et al., 2004). The immune stain was observed on epithelial alveolar cells and alveolar M $\phi$ s located in peribronchial tissue, although by immune staining, it was not possible to observe an imbalance between MMPs and TIMP-1. This study suggested that as more collagen becomes deposited, more activity of MMPs and their inhibitors will be present.

Although much remains to be done, the results offered by animal models have contributed greatly to understanding the genesis of the fibrotic process in PCM.

\subsubsection{Experimental attempts to control fibrosis}

Although currently several antifungal drugs are available for the treatment of PCM, as mentioned above in the diagnosis and treatment sections, the majority of them require prolonged therapies oscillating between 1 and 2 years (Borges-Walmsley et al., 2002). Additionally and even though these antifungal drugs can arrest the progression of the infection by restricting fungal proliferation, the principal sequelae of PCM, pulmonary fibrosis, persists, and it has been observed in both humans and murine models (Naranjo et al., 2010; Tobón et al., 2003). The fibrosis process generates progressive lung incapacity and it is probably a source of $P$. brasiliensis in future relapses of the disease (Borges-Walmsley et al., 2002). For these reasons, the need to search for new drugs or for the implementation of combined therapies has been indicated (Pappas, 2004), including experiments aiming to prevent or at least reduce the appearance of this serious sequela.

According to the recommendations given by the American Thoracic Society, the basic therapy for the treatment of patients suffering from pulmonary fibrosis includes certain immunosuppressive drugs based on the theory that the development of fibrosis is attributable to persistent inflammatory stimulus. However, the effect of using this kind of medication in humans with the chronic form of PCM remains unknown.

Recently, we evaluated the effect of two combined therapies (itraconazole + prednisolone) and (itraconazole + pentoxifylline) on the development of fibrosis using our murine model of pulmonary PCM, which reproduces the human infection from its inception until reaching the chronic form (Naranjo et al., 2011). In this study, the azolic derivative (itraconazole) was used because it is the antifungal treatment of choice for PCM (Restrepo et al., 2011; ShikanaiYasuda et al., 2006). In reference to the combined itraconazole + prednisolone therapy, the authors reported that although a significant reduction in both granulomatous inflammation and development of fibrosis was observed when this combined therapy was used, once it was ended, the fibrotic process reappeared and progressed over the levels observed when treatment with itraconazole alone was given. On the contrary, the use of itraconazole 
combined with pentoxifylline, a methylxanthine compound with recognized immune modulatory properties (Inoue et al., 2004; Tong et al., 2004) and antifibrotic effects when acting on fibroblast cells (Fang et al., 2003; Romanelli et al., 1997; Valente et al., 2003), generated good results.

The combined itraconazole + pentoxifylline therapy promptly reduced the granulomatous inflammation and caused a significant and rapid decrease of both thin reticulin and collagen fibers. The most important result was that thick fiber deposition of these proteins, which are considered fibrosis indicators, was reduced to normal levels, as seen in the uninfected mice, and remained low even after the end of the treatment. Considering fungal loads, it was demonstrated that the addition of pentoxifylline to itraconazole treatment did not produce additional deleterious effects on itraconazole antifungal activity; on the contrary, a tendency towards a faster reduction of fungal burdens was observed when the combined therapy was used (Naranjo et al., 2011). These beneficial effects were noted even when such combined therapy was started belatedly at 8 weeks post-infection, a time at which the fibrosis process was already established in the murine model.

The fact that in mice the combined itraconazole + pentoxifylline therapy promptly reduced the development of pulmonary fibrosis to levels lower than those seen with antifungal therapy alone, and that this effect was maintained even after treatment termination, presents a promising advance in the development and establishment of adjunctive immunotherapies for the treatment not only of pulmonary chronic PCM but also of several disorders or chronic infections that lead to the development of fibrosis.

These findings could imply not only a reduction of treatment costs but, more importantly, improvement in the chronic pulmonary PCM patients' quality of life.

\section{Pulmonary histopathology in patients with PCM: The counterpart of the experimental infection}

Reports on the pathologic features of pulmonary lesions in patients with the chronic adult form of PCM are scarce in the literature. The classical report was published by Tuder et al. (1985), who described five main pathologic aspects in the lungs of 12 patients with PCM as follows:

1. Pneumonic reaction characterized by acute alveolitis with histiocytes, few PMNs, lymphocytes and plasma cells;

2. Early granulomatous formation described as circumscribed epithelioid granulomas with reticulin fibers but with no dense collagen layer surrounding them;

3. Mature and healed granuloma with collagen in their periphery;

4. Mixed pattern (early and mature granuloma in the same pulmonary area);

5. Pulmonary fibrosis.

In addition, the pulmonary lesions could be either diffuse or circumscribed (Machado, 1965).

Most recently, a study that included 23 patients with lung samples obtained by surgical biopsy or at necropsy showed similar pathological features that included alveolar wall and interlobular septal thickening, as determined by the accumulation of inflammatory cells or, less frequently, by fibrosis; filling of the alveolar spaces with inflammatory exudate; granulomas with or without fibrosis; and other evidence of fibrosis, such as architectural distortion and honeycombing. Cavitation secondary to necrosis was also a common finding (Marchiori et al., 2011). 
As mentioned before, the PCM experimental animal models revealed a chronic, progressive infection that closely resembled human lesions but that did not reproduce certain histopathological aspects such as cavitated nodules, emphysema and the honeycombing pattern.

\section{Radiological aspects of PCM in humans and experimental mice}

Conventional HRCT has been applied as a noninvasive tool to evaluate and quantify pulmonary damage occurring in our experimental model of PCM (Lopera et al., 2010). This work has revealed that noninvasive conventional medical $x$-ray tomography is adequate to follow the sequential lung lesions in experimental PCM in mice. This procedure allowed detection of the main pathological patterns, the differential topographic distribution of the pulmonary lesions in both lungs, and their intensity.

The intensity of the inflammatory reaction, evaluated by histomorphometry, increased until the $12^{\text {th }}$ week of infection, with a subsequent decrease due to the tendency to form predominantly compact and more isolated pseudotumoral masses. This histopathological behavior was also detected by HRCT, as expressed by lung density measures (Hounsfield units, HU) that showed a significant correlation, mainly in the upper or hilar lung region (Figure 5).

When the mice were followed up sequentially, HRCT showed that $80 \%$ of them had peribronchial consolidations that persisted throughout the evaluation periods. Pulmonary consolidations were associated with a significant increase in upper lung density as compared with controls, $-263 \pm 29$ vs. $-426 \pm 8 \mathrm{HU}$ at week $4(p<0.001),-191 \pm 25$ vs. $-403 \pm 17$ $\mathrm{HU}$ at week $8(p<0.001)$, and $-269 \pm 43$ vs. $-445 \pm 12$ at week $12(p<0.001)$. At week 16, upper consolidations tended to decrease as well as the corresponding density, $-356 \pm 33$ vs. $-466 \pm 9$ $(p<0.01)$.

Histopathological analysis revealed that consolidation, as assessed by HRCT, was equivalent histologically to a confluent granulomatous reaction, while nodules corresponded to individual compact granulomas. During the same period of infection, confluent granulomas formed pseudotumoral masses that obstructed large bronchi. Discrete focal fibrosis was visible gradually around granulomas, but this finding was only evident with histopathology.

Comparing the above results with radiological findings in patients is difficult because the size of lungs, the resolution of the topographer and the protocols used.

In humans, assessment of disease progression and treatment outcome normally includes chest $\mathrm{x}$-rays and then $\mathrm{CT}$ studies. At the time of diagnosis and in patients with active disease, chest $x$-ray revealed interstitial and alveolar-interstitial infiltrates, often bilateral and symmetrical, occasionally confluent, located preferentially in the central and basal areas of the lung (pattern in butterfly wings) (do Valle et al., 1992; Trad et al., 2006). A study of radiological monitoring carried out in 173 patients with chronic PCM reported presence of reticular interstitial infiltrates in $89.3 \%$ of the cases and nodular in $54.5 \%$, bilateral alveolar in $45.4 \%$, and mixed (in butterfly wings) in $44.7 \%$. Emphysema was reported in $34.1 \%$, septal lines by $25.7 \%$, pleural thickening by $7.5 \%$. Nine cases $(6.8 \%)$ presented cavitations and three cases (2.2\%) giant nodules or masses (Trad et al., 2006).

$\mathrm{CT}$ proved superior to conventional radiographs in demonstrating early interstitial reticular and nodular infiltrates and showed abnormal findings in the majority of patients with chronic pulmonary PCM (more than 93\%). 

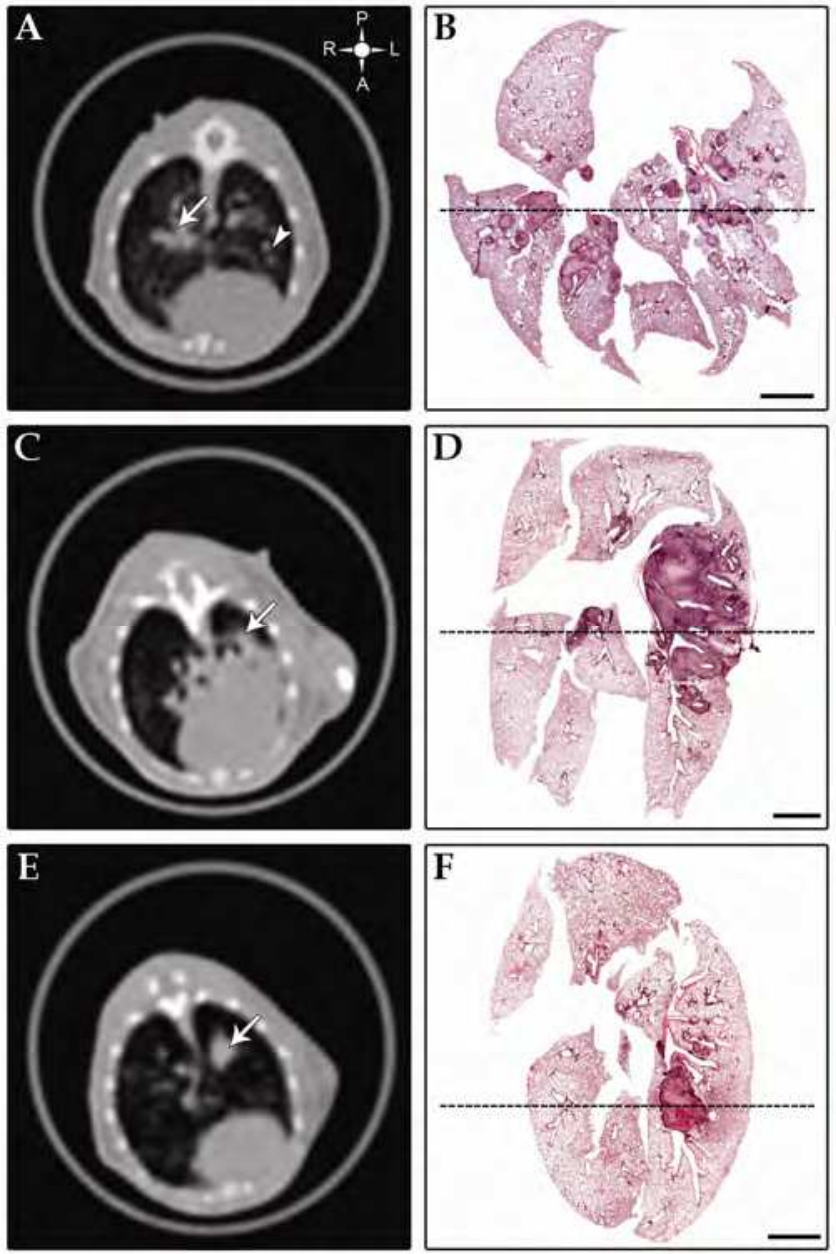

Fig. 5. Patterns of the main lung lesion as detected by conventional medical HRCT and histopathological methods in the experimental mouse PCM model. A, C, E correspond to HRCT images and B, D, F show the corresponding histopathological lesions taken in a coronal plane. The upper right symbol in (A) indicates posterior or dorsal (P), anterior or ventral (A), left $(\mathrm{L})$ and right $(\mathrm{R})$ regions. Dotted lines in $\mathrm{B}, \mathrm{D}$ and $\mathrm{F}$ show an approximated position of the tomographic section. (A) Large nodular lesion represented by a peribronquial consolidation (arrow) is located at right hilar region and other left small nodules are indicated by arrowhead. (B) Several nodules with varied sizes. (C) Confluent lesion expressed by left central peri-bronchial consolidation (arrow) extended from the hilum to large area of the parenchyma. (D) Consolidated areas of perivascular and justabronchial granulomatous lesions. (E) Pseudotumoral lesion defining a left central pulmonary mass (arrow). (F) Left central pseudotumoral mass obstructing the bronchus. Scale bar for HRCT images $=1 \mathrm{~cm}$. Scale bar for histopathological images $=2 \mathrm{~mm}$. Adapted from PLoS Negl Trop Dis 4(6): e726. doi:10.1371/journal.pntd.0000726.g005. 
The most frequent HRCT findings in patients with pulmonary PCM were ground-glass attenuation areas; small centrilobular, cavitated and large nodules; parenchymal bands; airspace consolidations; interlobular septal thickening; architectural distortion; traction bronchiectasis; paracicatricial emphysema and fibrosis. Most of those HRCT findings concentrated in the periphery and posterior regions involving all lung zones, with slight increased intensity in the middle zones (Funari et al., 1999; Marchiori et al., 2008, 2009; Muniz et al., 2002; Souza et al., 2006). The radiologic patterns described above in patients with pulmonary PCM were dependent on the stage of the disease and on the exclusion or inclusion of patients who had received previous treatment were excluded.
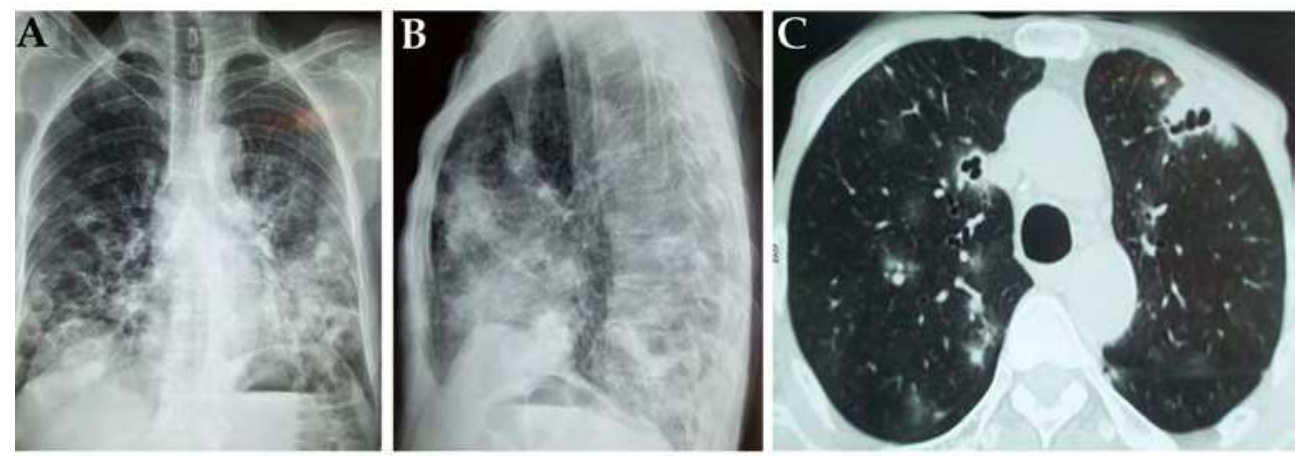

Fig. 6. Radiological findings in a patient with chronic pulmonary PMC at diagnosis.

(A, B) Postero-anterior chest and lateral radiographs showing bilateral reticulonodular and ground-glass opacities with cavitations. (C) HRCT shows consolidations, ground glass attenuations and cavitated masses.

\section{Final remarks}

Infection by $P$. brasiliensis is, no doubt, acquired only in the endemic areas of Central and South America, especially in Brazil. However, as the fungus exhibits the capacity to remain dormant in the tissues of the infected human host for extended periods and is, likewise, able to regain its vitality giving rise to overt disease, one may encounter the mycosis in individuals living in non-autochthonous areas, distant from those where the primary infection was acquired.

This is why it is imperative to keep informed physicians and other health-related professionals on this endemic mycosis and be prepared to include it among the differential diagnoses of disorders compatible with PCM. A detailed interrogation on the patient's former places of residence or visit should be obtained in order to focus the diagnosis. On the same token, $P$. brasiliensis should be taken into considerations whenever clinical samples and biopsies are being analyzed. It is only through knowledge that the specific diagnosis will be made in these difficult to diagnose non-autochthonous cases.

One of the main aims of this chapter was educational, namely, informing pneumologists and related professionals of the existence of this "tropical" disorder. It should be remembered that $P$. brasiliensis travels along with its host to any part of the world and that this host, now ill, may well be your own patient. 


\section{References}

Albeda, S.M., Smith, C.W. \& Ward, P.A. (1994). Adhesion molecules and inflammatory injury. FASEB J, Vol.8: 504-512, ISSN 0892-6638.

Bagaggli, E., Franco, M., Bosco, S. de M., Hebeler-Barbosa, F., Trinca, L.A. \& Montenegro, M.R. (2003). High frequency of Paracoccidioides brasiliensis infection in armadillos (Dasypus novemcinctus): an ecological study. Med Mycol,Vol. 41, No. 3, pp. 217-223, ISSN 1369-3786.

Barbosa, M. S., Bao, S. N., Andreotti, P. F., de Faria, F. P., Felipe, M. S., dos Santos-Feitosa, L., Mendes-Giannini, M. J. \& Soares, C. M. (2006). Glyceraldehyde-3-phosphate dehydrogenase of Paracoccidioides brasiliensis is a cell surface protein involved in fungal adhesion to extracellular matrix proteins and interaction with cells. Infect Immun, Vol. 74, No. 1, pp. 382-389, ISSN0019-9567.

Bárcenas, C., Cano, L. E., Cock A. M., Martínez, A. R. \& Restrepo, A. (2004). Expresión de metaloproteinas y sus inhibidores de tejido en un modelo murino de fibrosis pulmonar. Med-UNAB, Vol. 7, No.19, pp. 9-14, ISSN 0123-7047.

Barrozo, L.V., Benard, G., Silva, M.E., Bagagli, E., Marques, S.A. \& Mendes, R.P. (2010). First description of a cluster of acute/subacute paracoccidioidomycosis cases and its association with a climatic anomaly. PLoS Negl Trop Dis.Vol. 4: e643. ISSN 19352735.

Bedoya, V., McEwen, J.G., Tabares, A.M., Jaramillo, F.U. \& Restrepo, A. (1986). Pathogenesis of paracoccidioidomycosis: a histopathological study of the experimental murine infection. Mycopathologia, Vol. 94, No.3, pp. 133-144, ISSN 0301-486X.

Bellissimo-Rodrigues, F., Machado, A. \& Martinez, R. (2011). Paracoccidioidomycosis: epidemiological features of a 1,000 cases series from a hyperendemic area on the Southeast of Brazil. Am J Trop Med Hyg, Vol. 85, No.3, pp.546-50. ISSN 0002-9637.

Benard, G., Orii, N. M., Marques, H. H., Mendonça, M., Aquino, M. Z., Campeas, A. E., del Negro, G. B., Durandy, A. \& Duarte, A. J. (1994). Severe acute paracoccidioidomycosis in children. Pediatr Infect Dis J, Vol. 13, No. 6, pp. 510-515, ISSN 0891-3668.

Benard, G., Kavakama, J., Mendes-Giannini, M. J., Kono, A., Duarte, A. J. \& ShikanaiYasuda, M. A. (2005). Contribution to the natural history of paracoccidioidomycosis: identification of the primary pulmonary infection in the severe acute form of the disease--a case report. Clin Infect Dis, Vol. 40, No. 1, pp. e14. ISSN1537-6591.

Bethlem, E. P., Capone, D., Maranhao, B., Carvalho, C. R. \& Wanke, B. (1999). Paracoccidioidomycosis. Curr Opin Pulm Med, Vol.5, No. 5, pp. 319-325, ISSN 10705287.

Bialek, R., Ibricevic, A., Aepinus, C., Najvar, L. K., Fothergill, A. W., Knobloch, J. \& Graybill, J. R. (2000a). Detection of Paracoccidioides brasiliensis in tissue samples by a nested PCR assay. J Clin Microbiol, Vol. 38, No. 8, pp. 2940-2942, ISSN0095-1137.

Bialek, R., Ibrecevic, A., Fothergill, A. \& Begerow, D. (2000b). Small subunit ribosomal DNA sequences shows Paracoccidioides brasiliensis closely related to Blastomyces dermatitidis. J Clin Microbiol, Vol.38, No. 9, pp. 3190-3193, ISSN0095-1137.

Bittencourt, J.I., de Oliveira R.M. \& Coutinho Z.F. (2005). Paracoccidioidomycosis mortality in the State of Parana, Brazil, 1980/1998. Cad Saude Publica, Vol. 21, No. 6, pp. 1856 1864, ISSN 0102-311X. 
Blotta, M. H., Mamoni, R. L., Oliveira, S. J., Nouer, S. A., Papaiordanou, P. M., Goveia,A. \& Camargo, Z.P. (1999). Endemic regions of paracoccidioidomycosis in Brazil: a clinical and epidemiologic study of 584 cases in the southeast region. Am J Trop Med Hyg, Vol. 61, No. 3, pp. 390-394, ISSN0002-9637.

Bonifaz, A. (2010). Chapter 219: Paracoccidioidomicosis, in Bonifaz, A. (ed.), Micología Médica Básica, 3rd Ed. McGrow Hill, Mexico, pp. 259-270.

Bonifaz, A., Vázquez-González, D. \& Perusquía-Ortiz, A.M. (2011). Endemic systemic mycoses: coccidioidomycosis, histoplasmosis, paracoccidioidomycosis and blastomycosis. J Dtsch Dermatol Ges. Vol. 9, No. 9, pp.705-14. ISSN 1610-0387.

Borelli, D. (1972). Some ecological aspects of paracoccidioidomycosis. Proceedings Panamerican Symposium on Paracoccidioidomycosis, Washington: Pan American Health Organization, Washington, D:C., PAHO Scientific Publication No 254, pp. 59-64.

Borges-Walmsley, M. I., Chen, D., Shu, X. \& Walmsley, A. R. (2002). The pathobiology of Paracoccidioides brasiliensis.Trends Microbiol, Vol. 10, No.2, pp. 80-87, ISSN 0966$842 X$.

Brummer, E., Restrepo, A., Stevens, D.A., Azzi, R., Gómez, A.G., Hoyos, G., McEwen, J.G., Cano, L.E. \& de Bedout, C. (1984). Murine model of paracoccidioidomycosis production of fatal acute pulmonary or chronic pulmonary and disseminated disease. Immunological and pathological observations. J Exp Pathol, Vol.1, No. 3, pp. 241-255, ISSN0730-8485.

Brummer, E., Castañeda, E. \& Restrepo, A. (1993). Paracoccidioidomycosis: an update. Clin Microbiol Rev, Vol. 6, No. 2, pp. 89-117, ISSN 0893-8512.

Buitrago, M.J., Bernal-Martinez, L., Castelli, M.V., Rodríguez-Tudela, J.L. \& Cuenca-Estrella, M. (2011). Histoplasmosis and paracoccidioidomycosis in a non-endemic area: a review of cases and diagnosis. J Travel Med, Vol.18, No. 1, pp. 26-33, ISSN 17088305.

Burger, E., Miyaji, M., Sano, A., Calich, V. L., Nishimura, K. \& Lenzi, H. L. (1996). Histopathology of paracoccidioidomycotic infection in athymic and euthymic mice: a sequential study. Am J Trop Med Hyg, Vol. 55, No.2, pp. 235-242, ISSN 0002-9637.

Calich, V. L., Singer-Vermes, L. M., Siqueira, A. M. \& Burger, E. (1985). Susceptibility and resistance of inbred mice to Paracoccidioides brasiliensis. Br J Exp Pathol, Vol. 66, No.5, pp. 585-594, ISSN 0007-1021.

Calle, D., Rosero, S., Orozco, L.C., Camargo, D., Castañeda, E. \& Restrepo, A. (2001). Paracoccidioidomycosis in Colombia: an ecological study. Epidemiology Infection, Vol. 126, No. 2, pp. 309-315, ISSN 0950-2688.

Calvi, S. A., Soares, A. M., Peraçoli, M. T.,Franco, M., Ruiz, R. L. Jr., Marcondes-Machado, J., Fecchio, D., Mattos, M. C. \& Mendes, R. P. (2003). Study of bronchoalveolar lavage fluid in paracoccidioidomycosis: cytopathology and alveolar macrophage function in response to gamma interferon; comparison with blood monocytes. Microbes Infect, Vol. 5, No. 15, pp. 1373-1379, ISSN 1286-4579.

Campos, M. V., Penna, G. O., Castro, C. N., Morales, M. A., Ferreira, M. S. \& Santos, J. B. (2008). Paracoccidioidomycosis at Brasilia's university hospital. Rev Soc Bras Med Trop,Vol. 41, No. 2, pp. 169-172, ISSN 0037-8682.

Cano, L.E., Singer-Vermes, L.M., Costa, T.A., Mengel, J.O., Xidieh, C.F., Arruda, C., André, D.C., Vaz, C.A., Burger, E. \& Calich, V.L. (2000). Depletion of CD8 (+) T cells in vivo 
impairs host defense of mice resistant and susceptible to pulmonary paracoccidioidomycosis. Infect Immun, Vol.68, No. 1, pp. 352-359, ISSN 0019-9567.

Carlos, T. M. \& Harlan, J. M. (1990). Membrane proteins involved in phagocyte adherence to endothelium. Immunol Rev,Vol. 114, No. 1, pp. 5-27, ISSN 0105-2896.

Caro, E., González, A., Muñoz, C., Urán, M. E., Restrepo, A., Hamilton, A. J. \& Cano, L.E. (2008). Recognition of laminin by Paracoccidioides brasiliensis conidia: a possible mechanism of adherence to human type II alveolar cells. Med Mycol, Vol. 46, No. 8, pp. 795-804, ISSN 1369-3786.

Cock, A. M., Cano, L. E., Vélez, D., Aristizábal, B. H., Trujillo, J. \& Restrepo, A. (2000). Fibrotic sequelae in pulmonary paracoccidioidomycosis: histopathological aspects in BALB/c mice infected with viable and non-viable Paracoccidioides brasiliensis propagules. Rev Inst Med Trop Sao Paulo, Vol. 42, No. 2, pp. 59-66, ISSN 0036-4665.

Coimbra, Jr. C.E., Wanke, B., Santos, R.V., do Valle, A.C., Costa, R.L. \& Zancope-Oliveira, R.M. (1994). Paracoccidioidin and histoplasmin sensitivity in Tupi-Monde Amerindian populations from Brazilian Amazonia. Ann Trop Med Parasitol, Vol. 88, No. 2, pp. 197-207, ISSN 0003-4983.

Colombo, A. L., Tobón, A., Restrepo, A., Queiroz-Telles, F. \& Nucci, M. (2011). Epidemiology of endemic systemic fungal infections in Latin America. Med Mycol, Vol. 49, No. 8, pp.785-98. ISSN1460-2709.

Conti-Díaz, I.A. \& Calegari L.F. (1979). Paracoccidioidomycosis in Uruguay: its status and current problems. Bol Oficina Sanit. Panam, Vol. 86, No. 3, pp. 219-229, ISSN00300632.

Conti-Díaz, I. (2007). Point of view on the unknown ecological niche of Paracoccidioides brasiliensis. Our hypothesis of 1989: Present status and perspectives. Rev. Inst. Med. Trop. S. Paulo, Vol. 49, No. 2, pp. 131-134, ISSN0036-4665.

Coutinho, Z.F., Silva, D., Lazera, M., Petri, V., Oliveira, R.M., Sabroza, P. C. \& Wanke, B. (2002). Paracoccidioidomycosis mortality in Brazil (1980-1995). Cad Saude Publica, Vol. 18, No. 5, pp. 1441-1454, ISSN 0102-311X.

Da Silva, F. C., Svidzinski, T. I., Patussi, E. V., Cardoso, C. P., De Oliveira Dalalio, M. M. \& Hernandes, L. (2009). Morphologic organization of pulmonary granulomas in mice infected with Paracoccidioides brasiliensis. Am J Trop Med Hyg, Vol. 80, No.5, pp. 798804, ISSN 1476-1645.

Da Silva, M. B., Marques, A. F., Nosanchuk, J. D., Casadevall, A.,Travassos, L. R. \& Taborda, C. P. (2006). Melanin in the dimorphic fungal pathogen Paracoccidioides brasiliensis: effects on phagocytosis, intracellular resistance and drug susceptibility. Microbes Infect, Vol. 8, No. 1, pp. 197-205, ISSN1286-4579.

Datta, A., Scotton, C. J. \& Chambers, R. C. (2011). Novel therapeutic approaches for pulmonary fibrosis. Br J Pharmacol, Vol. 163, No.1, pp. 141-72, ISSN 1476-5381.

Defaveri, J., Rexkallah-Iwasso, M.T. \& Franco, M.F. (1982). Experimental pulmonary paracoccidioidomycosis in mice: morphology and correlation of lesions with humoral and cellular immune response. Mycophatologia, Vol. 77, No. 1, pp. 3-11, ISSN 0301-486X.

Essayag, S.M., Landaeta, M.E., Hartung, C., Magaldi, S., Spencer, L., Suárez, R., García, F. \& Pérez, E. (2002). Histopathologic and histochemical characterization of calcified structures in hamsters inoculated with Paracoccidioides brasiliensis. Mycoses, Vol.45, No.(9-10), pp. 351-357, ISSN0933-7407. 
Fang, C. C., Lai, M. N., Chien, C. T., Hung, K. Y., Tsai, C. C., Tsai, T. J. \& Hsieh, B. S. (2003). Effects of pentoxifylline on peritoneal fibroblasts and silica-induced peritoneal fibrosis. Perit Dial Int, Vol. 23, No.3, pp. 228-36, ISSN 0896-8608.

Fava-Netto, C., De Brito, T. \& Lacaz, C.S. (1961). Experimental South American blastomycosis of the guinea pig. Pathol Microbiol, Vol. 24, No. 2, pp. 192-206, ISSN0031-2959.

Flynn, J.L., Scanga, C.A., Tanaka, K.E. \& Chan, J. (1998). Effects of aminoguanidine on latent murine tuberculosis. J Immunol, Vol. 160, No.4 pp. 1796-1803, ISSN 0022-1767.

Flynn, J.L., Chan, J. \& Lin, P.L. (2011). Macrophages and control of granulomatous inflammation in tuberculosis. Mucosal Immunol, Vol.4, No.3, pp. 271-278, ISSN 19353456.

Fornazim, M. C., Balthazar, A., Quagliato, R., Mamoni, R. L., Garcia, C. \& Blotta, M. H. S. L. (2003). Evaluation of bronchoalveolar cells in pulmonary paracoccidioidomycosis. Eur Respir J, Vol. 22, No. 6, pp. 895-899, ISSN 0903-1936.

Franco, L., Najvar, L., Gómez, B. L., Restrepo, S., Graybill, J. R. \& Restrepo, A. (1998). Experimental pulmonary fibrosis induced by Paracoccidioides brasiliensis conidia: measurement of local host responses. Am J Trop Med Hyg, Vol. 58, No.4, pp. 424-30, ISSN 0002-9637.

Franco, M., Montenegro, M. R., Mendes, R. P., Marques, S. A., Dillon, N. L. \& Mota, N. G. (1987). Paracoccidioidomycosis: a recently proposed classification of its clinical forms. Rev Soc Bras Med Trop, Vol. 20, No. 2, pp.129-132, ISSN 0037-8682.

Franco, M., Bagagli, E., Scapolio, S. \& da Silva Lacaz, C. (2000). A critical analysis of isolation of Paracoccidioides brasiliensis from soil. Med Mycol, Vol. 38, No. 3, pp. 185-191, ISSN 1369-3786.

Funari, M., Kavakama, J., Shikanai-Yasuda, M. A., Castro, L. G., Bernard, G., Rocha, M. S., Cerri, G. G. \& Muller, N. L. (1999). Chronic pulmonary paracoccidioidomycosis (South American blastomycosis): high-resolution CT findings in 41 patients. AJR Am J Roentgenol, Vol. 173, No.1, pp. 59-64, ISSN 0361-803X.

Garcia-de-Alba, C., Becerril, C., Ruiz, V., Gonzalez, Y., Reyes, S., Garcia-Alvarez, J., Selman, M. \& Pardo, A. (2010). Expression of matrix metalloproteases by fibrocytes: possible role in migration and homing. Am J Respir Crit Care Med,Vol. 182, No.9, pp. 1144-52, ISSN 1535-4970.

Gaur, N. K., Klotz, S. A. \& Henderson, R. L. (1999). Overexpression of the Candida albicans ALA1 gene in Saccharomyces cerevisiae results in aggregation following attachment of yeast cells to extracellular matrix proteins, adherence properties similar to those of Candida albicans. Infect Immun, Vol. 67, No. 11, pp. 6040-6047, ISSN 0019-9567.

Goldman, D., Cho, Y., Zhao, M.L., Casadevall, A. \& Lee, S.C. (1996). Expression of inducible nitric oxide synthase in rat pulmonary Cryptococcus neoformans granulomas. Am J Pathol, Vol. 148, No. 4, pp. 1275-1282, ISSN 0002-9440.

Gomes, E., Wingeter, M. A., \& Svidzinski, T. I. (2008) Clinical-radiological dissociation in lung manifestations of paracoccidioidomycosis. Rev Soc Bras Med Trop, Vol. 41, No. 5, pp. 454-458, ISSN 1678-9849.

Gomes, G. M., Cisalpino, P. S., Taborda, C. P. \& de Camargo, Z. P. (2000). PCR for diagnosis of paracoccidioidomycosis. J Clin Microbiol, Vol. 38, No. 9, pp. 3478-3480, ISSN 0095-1137. 
Gómez, B. L., Figueroa, J. I., Hamilton, A. J., Diez, S., Rojas, M., Tobón, A. M., Hay, R. J. \& Restrepo, A. (1998). Antigenemia in patients with paracoccidioidomycosis: detection of the 87-kilodalton determinant during and after antifungal therapy. $J$ Clin Microbiol, Vol. 36, No. 11, pp. 3309-3316, ISSN0095-1137.

Gómez, B.L., Figueroa, J.I., Hamilton, A.J., Ortiz, B., Robledo, M.A., Hay, R.J. \& Restrepo, A. (1997). Use of monoclonal antibodies in diagnosis of paracoccidioidomycosis: new strategies for the detection of circulating antigens. J ClinMicrobiol, Vol. 35, No. 12, pp. 3278-3283, ISSN 0095-1137.

Gonçalves, A. J., Londero, A. T., Terra, G. M., Rozenbaum, R., Abreu, T. F. \& Nogueira, S. A. (1998). Paracoccidioidomycosis in children in the state of Rio de Janeiro (Brazil). Geographic distribution and the study of a "reservarea". Rev Inst Med Trop São Paulo, Vol. 40, No. 1, pp. 11-13, ISSN 0036-4665.

González, A., Sahaza, J. H., Ortiz, B. L., Restrepo, A. \& Cano, L. E. (2003). Production of proinflammatory cytokines during the early stages of experimental Paracoccidioides brasiliensis infection. Med Mycol, Vol. 41, No. 5, pp. 391-399, ISSN1369-3786.

González, A., Gómez, B. L., Díez, S., Hernández, O., Restrepo, A., Hamilton, A. J. \& Cano, L. E. (2005a). Purification and partial characterization of a Paracoccidioides brasiliensis protein with capacity to bind to extracellular matrix proteins. Infect Immun, Vol. 73, No. 5, pp. 2486-2495, ISSN 0019-9567.

González, A., Lenzi, H. L., Motta, E. M., Caputo, L., Sahaza, J. H., Cock, A. M., Ruiz, A. C., Restrepo, A. \& Cano, L. E. (2005b).Expression of adhesion molecules in lungs of mice infected with Paracoccidioides brasiliensis conidia. Microbes Infect, Vol. 7, No. 4, pp. 666-673, ISSN 1286-4579.

González, A., Caro, E., Muñoz, C., Restrepo, A., Hamilton, A. J. \& Cano, L .E. (2008a). Paracoccidioides brasiliensis conidia recognize fibronectin and fibrinogen which subsequently participate in adherence to human type II alveolar cells: involvement of a specific adhesin. Microb Pathog, Vol. 44, No. 5, pp. 389-401, ISSN 0882-4010.

González, A., Gómez, B. L., Muñoz, C., Aristizábal, B. H., Restrepo, A., Hamilton, A. J. \& Cano, L. E. (2008b). Involvement of extracellular matrix proteins in the course of experimental paracoccidioidomycosis. FEMS Immunol Med Microbiol, Vol. 53, No. 1, pp. 114-125, ISSN 0928-8244.

González, A., Lenzi, H. L., Motta, E. M., Caputo, L., Restrepo, A., \& Cano, L. E. (2008c). Expression and arrangement of extracellular matrix proteins in the lungs of mice infected with Paracoccidioides brasiliensis conidia. Int J Exp Pathol, Vol. 89, No. 2, pp. 106-116, ISSN 1365-2613.

González, A., Restrepo, A. \& Cano, L. E. (2008d). Pulmonary immune responses induced in BALB/c mice by Paracoccidioides brasiliensis conidia. Mycopathologia, Vol. 165, No. 45, pp. 313-330, ISSN 0301-486X.

Hahn, R. C., \& Hamdan, J. S. (2000). Effects of amphotericin B and three azole derivatives on the lipids of yeast cells of Paracoccidioides brasiliensis. Antimicrob Agents Chemother, Vol. 44, No. 7, pp. 1997-2000, ISSN 0066-4804.

Hamacher, J. \& Schaberg, T. (1994). Adhesion molecules in lung diseases. Lung, Vol. 172, No. 4, pp. 189-213, ISSN 0341-2040.

Hernández, O., Almeida, A. J., González, A., García, A. M., Tamayo, D., Cano, L. E., Restrepo, A. \& McEwen, J. G. (2010). A 32-kilodalton hydrolase plays an important 
role in Paracoccidioides brasiliensis adherence to host cells and influences pathogenicity. Infect Immun, Vol. 78, No. 12, pp. 5280-5286, ISSN 1098-5522.

Hsu, L.Y., Ng, E.S. \& Koh, L.P. (2010). Common and emerging fungal pulmonary infections. Infect Dis Clin North Am, Vol. 24, No. 3, pp. 557-577, ISSN 1557-9824.

Iabuki, K. \& Montenegro, M.R. (1979). Experimental paracoccidioidomycosis in the Syrian hamster: morphology, ultrastructure and correlation of lesions with presence of specific antigens and serum levels of antibodies. Mycopathologia, Vol. 67, No. 3, pp. 131-141, ISSN0301-486X.

Inoue, K., Takano, H., Yanagisawa, R. \& Sakurai, M. (2004). Anti-inflammatory Effect of Pentoxifylline. Chest, Vol. 126, No.1, pp. 321, ISSN 0012-3692.

Iovannitti, C.A., Finquelievich, J.L., Negroni, R. \& Elías-Costa, M.R. (1999). Histopathological evolution of experimental paracoccidioidomycosis in Wistar rats. Zentralbl Bakteriol, Vol.289, No. 2, pp. 211-216, ISSN0934-8840.

Izzo, A. A., Lovchik, J. A. \& Lipscomb, M. F. (1998). T and B cell independence of endothelial cell adhesion molecule expression in pulmonary granulomatous inflammation. Am J Respir Cell MolBiol, Vol. 19, No. 4, pp. 588-597, ISSN 1044-1549.

Kerr, I.B., de Oliveira, P.C. \& Lenzi, H.L. (1988). Connective matrix organization in chronic granulomas of experimental paracoccidioidomycosis. Mycopathologia, Vol. 103, No.1, pp. 11-20, ISSN 0301-486X.

Koishi, A. C., Vituri, D. F., DionízioFilho, P. S., Sasaki, A. A., Felipe, M. S. \& Venancio, E. J. (2010). A semi-nested PCR assay for molecular detection of Paracoccidioides brasiliensis in tissue samples. Rev Soc Bras Med Trop, Vol. 43, No. 6, pp. 728-730, ISSN 1678-9849.

Lacaz, C. S., Porto, E., Martins, J.E.C., Heins-Vaccari, E.M. \& Melo, N.T. (2002). Paracoccidioidomicose, in Lacaz C, Porto E, Martins JEC., Heins-Vaccari, E.M., Melo, N.T. (eds.), Tratado de Micología Médica Lacaz. 9th ed. Servier. São Paulo, Brazil, pp. 639-729.

Livonesi, M.C., Souto, J.T., Campanelli, A.P., Maffei, C.M., Martinez, R., Rossi, M.A. \& Da Silva, J.S. (2008). Deficiency of IL-12p40 subunit determines severe paracoccidioidomycosis in mice. Med Mycol, Vol. 46, No.7, pp. 637-646, ISSN 13693786.

Livonesi, M.C., Rossi, M.A., de Souto, J.T., Campanelli, A.P., de Sousa, R.L., Maffei, C.M., Ferreira, B.R., Martinez, R. \& da Silva, J.S. (2009). Inducible nitric oxide synthasedeficient mice show exacerbated inflammatory process and high production of both Th1 and Th2 cytokines during paracoccidioidomycosis. Microbes Infect, Vol. 11, No.1, pp. 123-132, ISSN 1286-4579.

Londero, A. T. (1986). Paracoccidioidomicose: Patogenia, formas clinicas, manifestacões pulmonares e diagnostico. J Pneumol (Brazil), Vol. 12, No. 1, pp. 41-57, ISSN01023586.

Londero, A. T., Rios-Gonçalves, A. J., Terra, G. M. \& Nogueira, S. A. (1996). Paracoccidioidomycosis in Brazilian children. A critical review (1911-1994). Arq Bras Med, Vol. 70, No. 4, pp. 197-203, ISSN.0365-0723 .

Lopera, D., Naranjo, T., Hidalgo, J. M., de Oliveira Pascarelli, B. M., Patiño, J. H., Lenzi, H. L., Restrepo, A. \& Cano, L. E. (2010). Pulmonary abnormalities in mice with paracoccidioidomycosis: a sequential study comparing high resolution computed 
tomography and pathologic findings. PLoS Negl Trop Dis, Vol. 4, No.6, pp. e726, ISSN 1935-2735.

Lopera, D., Naranjo, T. W., Cruz, O. G., Restrepo, A., Cano, L. E. \& Lenzi, H. L. (2011). Structural and topographic dynamics of pulmonary histopatology and local cytokine profiles in mice infected with Paracoccidioides brasiliensis conidia. PLoS Neglected Tropical Diseases, Vol.5, No.7, pp. e1232, ISSN 1935-2735.

Machado, J.M.J. \& Teixeira G.A. (1965). Das sequelas da blastomicose Sul-Americana. Hospital, Vol. 68, No. X, pp.141-147.

Marchiori, E., Escuissato, D.L., Souza, A.S.Jr., Barillo, J.L., Warszawiak, D. \& de Souza, A.S. (2008). Computed tomography findings in patients with tracheal paracoccidioidomycosis. J Comput Assist Tomogr, Vol. 32, No.5, pp. 788-791, ISSN 1532-3145.

Marchiori, E., Valiante, P.M., Mano, C. M., Zanetti, G., Escuissato, D. L., Souza, A. S. Jr., \& Capone, D. (2011). Paracoccidioidomycosis: High-resolution computed tomography-pathologic correlation. Eur J Radiol, Vol. 77, No. 1, pp. 80-84, ISSN 1872-7727.

Masinovsky, B., Urdal, D. \& Gallatin, W. M. (1990). IL-4 acts synergistically with IL-1 beta to promote lymphocyte adhesión to microvascular endothelium by induction of vascular cell adhesion molecule-1. J Immunol, Vol. 145, No. 9, pp. 2886-2895, ISSN0022-1767.

Matute, D. R., Sepulveda,V. E., Quesada, L. M., Goldman, G. H., Taylor, J. W., Restrepo, A. \& McEwen, J. G. (2006). Microsatellite analysis of three phylogenetic species of Paracoccidioides brasiliensis. J Clin Microbiol, Vol.44, No. 6, pp. 2153-2157, ISSN.

Mayayo, E., Lopez-Aracil, V., Fernandez-Torres, B., Mayayo, R. \& Dominguez, M. (2007). Report of an imported cutaneous disseminated case of paracoccidioidomycosis. Rev Iberoam Micol, Vol.24, No.1, pp. 44-46, ISSN 1130-1406.

McEwen, J.G., Bedoya, V., Patiño, M.M., Salazar, M.E. \& Restrepo, A. (1987). Experimental murine paracoccidioidomycosis induced by the inhalation of conidia. J Med Vet Mycol, Vol. 25, No. 3, pp. 165-175, ISSN0268-1218.

McMahon, J. P., Wheat, J., Sobel, M. E., Pasula, R., Downing, J. F. \& Martin, W. J. (1995). Murine laminin binds to Histoplasma capsulatum. A possible mechanism of dissemination. J Clin Invest, Vol. 96, No. 2, pp. 1010-1017, ISSN0021-9738.

Meltzer, E. B. \& Noble, P. W. (2008). Idiopathic pulmonary fibrosis. Orphanet J Rare Dis, Vol. 3, No. 1, pp. 8, ISSN 1750-1172.

Mendes, R. P. (1994). The gamut of clinical manifestations, in Franco, M., Lacaz, C., Restrepo, A., \& del Negro, G (eds). Paracoccidioidomycosis, CRC Press, Boca Raton, FL, pp. 233-258.

Moreira, A. P., Campanelli, A. P., Cavassani, K. A., Souto, J. T., Ferreira, B. R., Martinez, R., Rossi, M. A. \& Silva, J. S. (2006). Intercellular adhesion molecule-1 is required for the early formation of granulomas and participates in the resistance of mice to the infection with the fungus Paracoccidioides brasiliensis. Am J Pathol, Vol. 169, No. 4, pp. 1270-1281, ISSN0002-9440.

Morejon, K.M., Machado, A.A. \& Martinez, R. (2009). Paracoccidioidomycosis in patients infected with and not infected with human immunodeficiency virus: a case-control study. Am J Trop Med Hyg, Vol. 80, No. 3, pp. 359-366, ISSN1476-1645. 
Moscardi, M.\& Franco, M.F. (1980). Experimental paracoccidioidomycosis in mice. I. Immunopathological aspects of intraperitoneal infection. Rev Inst Med Trop Sao Paulo, Vol.22, No.6, pp. 286-293, ISSN 0036-4665

Mukhopadhyay, S. \& Gal, A.A. (2010). Granulomatous lung disease: an approach to the differential diagnosis. Arch Pathol Lab Med, Vol.134, No.5, pp. 667-690, ISSN 15432165.

Muniz, M.A., E, M., Magnago, M., Moreira, L.B. \& de Almeida Junior, J. (2002). Paracoccidioidomicose pulmonar - aspectos na tomografia computadorizada de alta resolução. Radiol Bras, Vol. 35, No.3, pp. 147-154, ISSN 0100-3984

Naranjo, M. S., Trujillo, M., Múnera, M. I., Restrepo, P., Gómez, I., \& Restrepo, A. (1990). Treatment of paracoccidioidomycosis with itraconazole. J Med Vet Mycol, Vol. 28, No. 1, pp. 67-76, ISSN 0268-1218.

Naranjo, T. W., Lopera, D. E., Diaz-Granados, L. R., Duque, J. J., Restrepo, A. \& Cano, L. E. (2010). Histopathologic and immunologic effects of the itraconazole treatment in a murine model of chronic pulmonary paracoccidioidomycosis. Microbes Infect, Vol. 12, No.14-15, pp. 1153-62, ISSN 1769-714X.

Naranjo, T. W., Lopera, D. E., Diaz-Granados, L. R., Duque, J. J., Restrepo, A. \& Cano, L. E. (2011). Combined itraconazole-pentoxifylline treatment promptly reduces lung fibrosis induced by chronic pulmonary paracoccidioidomycosis in mice. Pulm Pharmacol Ther, Vol. 24, No.1, pp. 81-91, ISSN 1522-9629.

Nascimento, F.R.F., Calich, V.L.G., Rodrigues, D. \& Russo, M. (2002). Dual role of nitric oxide in paracoccidioidomycosis: essential for resistance but overproduction associated with susceptibility. J Immunol, Vol. 168, No.9 , pp. 4593-4600, ISSN 0022-1767.

Nathan, C., \& Shiloh, M. U. (2000). Reactive oxygen and nitrogen intermediates in the relationship between mammalian host and microbial pathogens. Proc Natl Acad Sci USA, Vol.97, No. 16, pp. 8841-8848, ISSN 0027-8424.

Newman, S. L., Goote, L., Gabay, J. E. \& Selsted, M. E. (2000).Identification of constituents of human neutrophil azurophil granules that mediated fungistasis against Histoplasma capsulatum. Infect Immun, Vol. 68, No. 10, pp. 5668-5672, ISSN0019-9567.

Niño-Vega, G. A., Calcagno, A. M., San-Blas, G., San-Blas, F., Gooday, G. W. \& Gow, N. A. (2000). RFLP analysis reveals marked geographical isolation between strains of Paracoccidioides brasiliensis. Med Mycol, Vol. 38, No. 6, pp. 437-441, ISSN1369-3786.

Nishikaku, A. S., Sanchez-Molina, R. F., Ribeiro, L. C., Scavone, R., Albe, B. P., SilvaCunha, C. \& Burger, E. (2009). Nitric oxide participation in granulomatous response induced by Paracoccidioides brasiliensis infection in mice. Med Microbiol Immunol, Vol. 198, No. 2, pp.123-135, ISSN 1432-1831.

Nogueira, M. G., Andrade, G. M., \& Tonelli, E. (2006). Clinical evolution of paracoccidioidomycosis in 38 children and teenagers. Mycopathologia, Vol. 161, No. 2, pp. 73-81, ISSN 0301-486X.

Nucci, M., Colombo, A.L. \& Queiroz-Telles, F. (2009). Paracoccidioidomycosis. Curr Fungal Infect Rep., Vol. 3, No. 1, pp. 15-20, ISSN 1936-3761.

Osborn, L., Hession, C., Tizard, R., Vasallo, C., Luhowsky, S., Chi-Rosso, G. \& Lobb, R. (1989).Direct expression of vascular cell adhesion molecule-1, a cytokine-induced endotelial protein that binds to lymphocytes. Cell, Vol. 59, No. 6, pp. 1203-1211, ISSN0092-8674. 
Pappas, P. G. (2004). Immunotherapy for invasive fungal infections: from bench to bedside. Drug Resist Updat, Vol. 7, No.1, pp. 3-10, ISSN 1368-7646.

Pardo, A. \& Selman, M. (2006). Matrix metalloproteases in aberrant fibrotic tissue remodeling. Proc Am Thorac Soc, Vol. 3, No.4, pp. 383-388, ISSN 1546-3222.

Peraçoli, M.T.S., Mota, N.G.S. \& Montenegro, M.R. (1982). Experimental paracoccidioidomycosis in the Syrian hamster. Morphology and correlation of lesions with humoral and cell mediated immunity. Mycopathologia, Vol. 79, No. 1, pp. 7-17, ISSN0301-486X.

Pereira, R. M., Bucaretchi, F., Barison-Ede, M., Hessel, G. \& Tresoldi, A. T. (2004). Paracoccidioidomycosis in children: clinical presentation, follow-up and outcome. Rev Inst Med Trop São Paulo, Vol. 46, No. 3, pp. 127-131, ISSN 0036-4665.

Pilewski, J. M. \& Albelda, S. M. (1993). Adhesion molecules in the lung. An overview. Am Rev Respir Dis, Vol. 148, No. 6, pp. S31-37, ISSN0003-0805.

Pinzan, C.F., Ruas, L.P., Casabona-Fortunato, A.S., Carvalho, F.C. \& Roque-Barreira, M. C. (2010). Immunological basis for the gender differences in murine Paracoccidioides brasiliensis infection. PLoS ONE, Vol. 5, No. 5, pe10757. ISSN 1932-6203.

Poisson, D., Heitzmann, A., Mille, C., Muckensturm, B., Dromer, F., Dupont, B. \& Hocqueloux, L. (2007). Paracoccidioides brasiliensis in a brain abscess: First French case. J Mycol Med, Vol. 17, pp. 114-118, ISSN1156-5233.

Popi, A.F., Godoy, L.C., Xander, P., Lopes, J.D. \& Mariano, M. (2008). B-1 cells facilitate Paracoccidioides brasiliensis infection in mice via IL-10 secretion. Microbes Infect, Vol.10, No.7, pp. 817-824, ISSN 1286-4579.

Prado, M., da Silva, M. B., Laurenti, R., Travassos, L. R. \& Taborda, C. P. (2009). Mortality due to systemic mycoses as a primary cause of death or in association with AIDS in Brazil: a review from 1996 to 2006. Mem Inst Oswaldo Cruz, Vol.104, No. 3, pp. 513521, ISSN 1678-8060.

QuagliatoJr, R., Grangeia, A. T., de Massucio, R. A., De Capitani, E. M., RezendeSde, M. \& Balthazar, A. B. (2007). Association between paracoccidioidomycosis and tuberculosis: reality and misdiagnosis. J Bras Pneumol, Vol.33, No. 3, pp. 295-300, ISSN 1806-3756.

Ramos, E. S, \& Saraiva, L. E. (2008). Paracoccidioidomycosis. Dermatol Clin, Vol. 26, No. 2, pp. 257-269, ISSN 0733-8635.

Restrepo, A., McEwen, J.G. \& Castañeda, E. (2001). The habitat of Paracoccidioides brasiliensis: how far from solving the riddle? Med Mycol, Vol. 39, No. 3, pp. 233-241, ISSN 13693786.

Restrepo, A., Benard, G., de Castro, C. C., Agudelo, C. A. \& Tobón, A. M. (2008). Pulmonary paracoccidioidomycosis. Semin Respir Crit Care Med, Vol. 29, No.2, pp. 182-97, ISSN 1069-3424.

Restrepo, A., \& Tobón, A.M. (2009). Paracoccidioides brasiliensis, in Mandell, G. L., Bennett, J. E., \& Dolin, R., (eds), Mandell, Douglas and Bennett's Principles and Practice of Infectious Diseases, 7th ed. Elsevier, Philadelphia, pp. 3357-3363.

Restrepo, A., González, A. \& Agudelo, C.A. (2011). Chapter 21: Paracoccidioidomycosis, inW. Dismukes, C. Kauffman, P. Pappas, J. Sobel (eds): Essentials of Medical Mycology, 2nd Ed.: Springer, N.Y, N.Y., pp 367-385. 
Restrepo, S., Tobón, A., Trujillo, J. \& Restrepo, A. (1992). Development of pulmonary fibrosis in mice during infection with Paracoccidioides brasiliensis conidia. J Med Vet Mycol, Vol.30, No. 3, pp. 173-184, ISSN0268-1218.

Ricci, G., Mota, F. T., Wakamatsu, A., Serafim, R. C., Borra, R. C. \& Franco, M. (2004). Canine paracoccidioidomycosis. Med Mycol, Vol.42, No. 4, pp. 379-383, ISSN1369-3786.

Richini-Pereira, V.B., Bosco, S.M.G., Griese, J., Theodoro, R.C., Macoris, S.A.G., Silva, R.J., Barrozo, L., Tavares, P.M.S. \& Zancopé-Oliveira, R.M. (2008). Molecular detection of Paracoccidioides brasiliensis in road-killed wild animals. Med Mycol, Vol.46, No. 1, pp. 35-40, ISSN1369-3786.

Rodrigues, M. L., Dos Reis, G., Puccia, R., Travassos, L. R. \& Alviano, C. S. (2003). Cleavage of human fibronectin and other basement membrane-associated proteins by a Cryptococcus neoformans serine proteinase. Microb Pathog, Vol. 34, No. 2, pp. 65-71, ISSN0882-4010.

Romanelli, R. G., Caligiuri, A., Carloni, V., De Franco, R., Montalto, P., Ceni, E., Casini, A., Gentilini, P. \& Pinzani, M. (1997). Effect of pentoxifylline on the degradation of procollagen type I produced by human hepatic stellate cells in response to transforming growth factor-beta 1. Br J Pharmacol, Vol. 122, No.6, pp. 1047-54, ISSN 0007-1188.

San-Blas, G., Niño-Vega, G. \& Iturriaga, T. (2002). Paracoccidioides brasiliensis and paracoccidioidomycosis: Molecular approaches to morphogenesis, diagnosis, epidemiology, taxonomy and genetics. Med Mycol, Vol.40, No. 3, pp. 225-242, ISSN1369-3786.

Santo, A.H. (2008). Paracoccidioidomycosis-related mortality trend, state of São Paulo, Brazil: a study using multiple causes of death. Rev Panam Salud Publica, Vol.23, No.5, pp. 313-324, ISSN 1020-4989.

Severo, L. C., Roesch, E. W., Oliveira, E. A., Rocha, M. M. \& Londero, A. T. (1998). Paracoccidioidomycosis in women. Rev. Iberoam. Micol., Vol. 15, No. 2, pp. 88-89, ISSN1130-1406.

Shankar, J., Restrepo, A., Clemons, K.V. \& Stevens, D.A. (2011). Paracoccidioidomycosis: hormones and the resistance of women. Clinical Microbiology Reviews, Vol. 24, No. 2, pp. 296-313, ISSN1098-6618.

Shikanai-Yasuda, M. A., Benard, G., Higaki, Y., Del Negro, G. M., Hoo, S., Vaccari, E. H., Gryschek, R. C., Segurado, A. A., Barone, A. A. \& Andrade, D. R. (2002). Randomized trial with itraconazole, ketoconazole and sulfadiazine in paracoccidioidomycosis. Med Mycol, Vol. 40, No. 4, pp. 411-417, ISSN1369-3786.

Shikanai-Yasuda, M., Queiroz-Telles, F., Poncio, R., Lopes, A. \& Moretti, M. (2006). Guideliness in paracoccidioidomycosis. Rev. Soc. Bras. Med. Trop, Vol. 39, No.3, pp. 297-310, ISSN 0037-8682.

Shikanai-Yasuda, M. A., Conceição, Y. M., Kono, A., Rivitti, E., Campos, A. F. \& Campos, S. V. (2008). Neoplasia and paracoccidioidomycosis. Mycopathologia, Vol. 165, No. 4-5, pp. 303-312, ISSN 0301-486X.

Simões, L.B., Marques, S.A. \& Bagagli, E. (2004). Distribution of paracoccidioidomycosis: determination of ecologic correlates through spatial analyses. Med Mycol, Vol. 42, No. 6, pp. 517-523, ISSN1369-3786.

Soares, A.M., Rezkallah-Iwasso, M.T., Oliveira, S.L., Peraçoli, M.T., Montenegro, M.R. \& Musatti, C.C. (2000). Experimental paracoccidioidomycosis in high and low 
antibody responder mice of Selection IV-A. Med Mycol. Vol. 38, No.4, pp. 309-315, ISSN1369-3786.

Souto, J.T., Figueiredo, F., Furlanetto, A., Pfeffer, K., Rossi, M.A. \& Silva, J.S. (2000). Interferon-gamma and tumor necrosis factor-alpha determine resistance to Paracoccidioides brasiliensis infection in mice. Am J Pathol, Vol.156, No.5, pp. 18111820, ISSN 0002-9440.

Souza, A.S., Jr., Gasparetto, E.L., Davaus, T., Escuissato, D.L. \& Marchiori, E. (2006). Highresolution CT findings of 77 patients with untreated pulmonary paracoccidioidomycosis. AJR Am J Roentgenol, Vol. 187, No.5, pp. 1248-1252, ISSN 1546-3141.

Teixeira, M. M., Theodoro, R. C., de Carvalho, M. J., Fernandes, L., Paes, H. C., Hahn, R. C., Mendoza, L., Bagagli, E., San-Blas, G. \& Felipe, M. S. (2009). Phylogenetic analysis reveals a high level of speciation in the Paracoccidioides genus. Mol Phylogenet Evol, Vol. 52, No. 2, pp. 273-283, ISSN1095-9513.

Tobón, A. M., Gómez, I., Franco, L. \& Restrepo, A. (1995). Seguimiento post-terapia en pacientes con paracoccidioidomicosis tratados con itraconazol. Rev Colomb Neumol, Vol. 7, No. X, pp. 74-78, ISSN0121-5426.

Tobón, A. M., Agudelo, C. A., Osorio, M. L., Alvarez, D. L., Arango, M., Cano, L. E. \& Restrepo, A. (2003). Residual pulmonary abnormalities in adult patients with chronic paracoccidioidomycosis: prolonged follow-up after itraconazole therapy. Clin Infect Dis, Vol. 37, No. 7, pp. 898-904, ISSN1537-6591.

Tong, Z., Chen, B., Dai, H., Bauer, P. C., Guzman, J. \& Costabel, U. (2004). Extrinsic allergic alveolitis: inhibitory effects of pentoxifylline on cytokine production by alveolar macrophages. Ann Allergy Asthma Immunol, Vol. 92, No.2, pp. 234-239, ISSN 10811206.

Torrado, E., Castañeda, E., de la Hoz, F. \& Restrepo A. (2000). Paracoccidioidomicosis: definición de las áreas endémicas de Colombia. Biomédica, Vol.20, No. 4, pp. 327334, ISSN.0120-4157.

Torres, I., García, A. M., Hernández, O., González, A., McEwen, J. G., Restrepo, A. \& Arango, M. (2010). Presence and expression of the mating type locus in Paracoccidioides brasiliensis isolates. Fung Genet Biol. Vol. 47, No. 4, pp. 373-380, ISSN1096-0937.

Tracey, K. J. \& Cerami, A. (1994). Tumor necrosis factor: a pleiotropic cytokine and therapeutic target. Ann Rev Med, Vol. 45, No. 1, pp. 491-503, ISSN0066-4219.

Trad, H.S., Trad, C.S., Junior, J.E. \& Muglia, V.F. (2006). Revisão radiológica de 173 casos consecutivos de paracoccidioidomicose. Radiol Bras, Vol.39, No.3, pp. 175-179, ISSN 0100-3984.

Tuder, R. M., el Ibrahim, R., Godoy, C. E. \& De Brito, T. (1985). Pathology of the human pulmonary paracoccidioidomycosis. Mycopathologia, Vol. 92, No. 3, pp. 179-188, ISSN0301-486X.

Valente, E. G., Vernet, D., Ferrini, M. G., Qian, A., Rajfer, J. \& Gonzalez-Cadavid, N. F. (2003). L-arginine and phosphodiesterase (PDE) inhibitors counteract fibrosis in the Peyronie's fibrotic plaque and related fibroblast cultures. Nitric Oxide, Vol. 9, No.4, pp. 229-44, ISSN 1089-8603. 
Vigna, A.F., Almeida, S.R., Xander, P., Freymuller, E., Mariano, M. \& Lopes, J.D. (2006). Granuloma formation in vitro requires B-1 cells and is modulated by Paracoccidioides brasiliensis gp43 antigen. Microbes Infect, Vol.8, No.3, pp. 589-597, ISSN 1286-4579.

Walker, S. L., Pembroke, A. C., Lucas, S. B. \& Vega-Lopez, F. (2008). Paracoccidioidomycosis presenting in the UK. Br J Dermatol, Vol. 158, No. 3, pp. 624-626, ISSN0007-0963.

Wasylnka, J. A. \& Moore, M. M. (2000). Adhesion of Aspergillus species to extracellular matrix proteins: evidence for involvement of negatively charged carbohydrates on the conidial surface. Infect Immun, Vol. 68, No. 6, pp. 3377-3384, ISSN0019-9567.

Wynn, T. A. (2007). Common and unique mechanisms regulate fibrosis in various fibroproliferative diseases. J Clin Invest, Vol. 117, No.3, pp. 524-529, ISSN 0021-9738.

Xidieh, C. F., Lenzi, H. L., Calich, V. L. \& Burger, E. (1999). Influence of the genetic background on the pattern of lesions developed by resistant and susceptible mice infected with Paracoccidioides brasiliensis. Med Microbiol Immunol, Vol. 188, No.1, pp. 41-9, ISSN 0300-8584.

Yokomura, I., Iwasaki, Y., Nagata, K., Nakanishi, M., Natsuhara, A., Harada, H., Kubota, Y., Ueda, M., Inaba, T. \& Nakagawa, M. (2001). Role of intercellular adhesion molecule 1 in acute lung injury induced by candidemia. Exp Lung Res, Vol. 27, No. 5, pp. 417431, ISSN0190-2148.

Yu, M. L. \& Limper, A. H. (1997). Pneumocystis carinii induces ICAM-1 expression in lung epithelial cells through a TNF-alpha-mediated mechanism. Am J Physiol, Vol. 273, No. 6, pp. L1103-1111, ISSN0002-9513. 


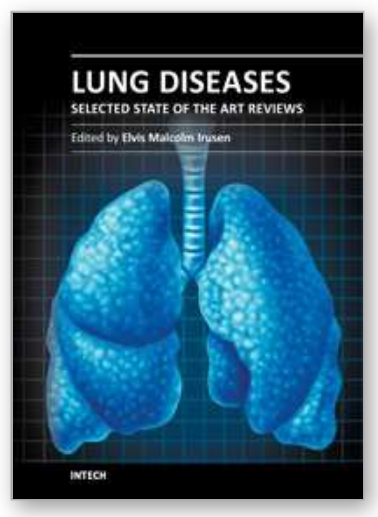

\section{Lung Diseases - Selected State of the Art Reviews}

Edited by Dr. Elvisegran Malcolm Irusen

ISBN 978-953-51-0180-2

Hard cover, 690 pages

Publisher InTech

Published online 02, March, 2012

Published in print edition March, 2012

The developments in molecular medicine are transforming respiratory medicine. Leading clinicians and scientists in the world have brought their knowledge and experience in their contributions to this book. Clinicians and researchers will learn about the most recent advances in a variety of lung diseases that will better enable them to understand respiratory disorders. This treatise presents state of the art essays on airways disease, neoplastic diseases, and pediatric respiratory conditions. Additionally, aspects of immune regulation, respiratory infections, acute lung injury/ARDS, pulmonary edema, functional evaluation in respiratory disorders, and a variety of other conditions are also discussed. The book will be invaluable to clinicians who keep up with the current concepts, improve their diagnostic skills, and understand potential new therapeutic applications in lung diseases, while scientists can contemplate a plethora of new research avenues for exploration.

\section{How to reference}

In order to correctly reference this scholarly work, feel free to copy and paste the following:

Luz E. Cano, Ángel González, Damaris Lopera, Tonny W. Naranjo and Ángela Restrepo (2012). Pulmonary Paracoccidioidomycosis: Clinical, Immunological and Histopathological Aspects, Lung Diseases - Selected State of the Art Reviews, Dr. Elvisegran Malcolm Irusen (Ed.), ISBN: 978-953-51-0180-2, InTech, Available from: http://www.intechopen.com/books/lung-diseases-selected-state-of-the-art-reviews/pulmonaryparacoccidioidomycosis-clinical-immunological-and-histopathological-aspects

\section{INTECH}

open science | open minds

\section{InTech Europe}

University Campus STeP Ri

Slavka Krautzeka 83/A

51000 Rijeka, Croatia

Phone: +385 (51) 770447

Fax: +385 (51) 686166

www.intechopen.com

\section{InTech China}

Unit 405, Office Block, Hotel Equatorial Shanghai

No.65, Yan An Road (West), Shanghai, 200040, China

中国上海市延安西路65号上海国际贵都大饭店办公楼 405 单元

Phone: +86-21-62489820

Fax: $+86-21-62489821$ 
(C) 2012 The Author(s). Licensee IntechOpen. This is an open access article distributed under the terms of the Creative Commons Attribution 3.0 License, which permits unrestricted use, distribution, and reproduction in any medium, provided the original work is properly cited. 